\title{
Magmatismo máfico associado ao Granito Encruzilhada do Sul, RS: implicações para a geração do magmatismo granítico pós-colisional do Cinturão Dom Feliciano
}

\author{
Maciel Gilmar JACOBS ${ }^{1}$, Ruy Paulo PHILIPP², Edinei KOESTER ${ }^{2}$ \& Lauro V.S. NARDI²
}

\author{
Programa de Pós-Graduação em Geociências, Universidade Federal do Rio Grande do Sul. Av. Bento Gonçalves, 9.500, CEP \\ 91.540-000, Porto Alegre, RS, Brasil (maciel.jacobs@ufrgs.br). \\ Centro de Estudos em Petrologia e Geoquímica, Instituto de Geociências, Universidade Federal do Rio Grande do Sul. Av. \\ 2 Bento Gonçalves, 9.500, CEP 91.540-000, Porto Alegre, RS, Brasil (ruy.philipp@ufrgs.br, koester@ufrgs.br, lauro.nardi@ \\ ufrgs.br).
}

Jacobs, M. G., Philipp, R.P., Koester, E. \& Nardi, L.V.S. 2018. Magmatismo máfico associado ao Granito Encruzilhada do Sul, RS: implicaç̃̃es para a geração do magmatismo granítico pós-colisional do Cinturão Dom Feliciano. Pesquisas em Geociências, 46: e0665. DOI: https://doi.org/10.22456/1807-9806.88648

\begin{abstract}
Resumo. A integração entre o mapeamento geológico com estudos petrográficos e geoquímicos permitiu caracterizar a evolução petrológica do Granito Encruzilhada do Sul (GES). Este maciço ocorre na parte norte do Batólito Pelotas, porção leste do Cinturão Dom Feliciano. No interior do GES ocorrem pequenos corpos de dioritos e zonas ricas em enclaves máficos, representando uma interação de mistura física entre os magmas ácido e básico. Fácies graníticas com alto teor de minerais máficos e de composição intermediária a ácida são interpretados como rochas híbridas e relacionadas a mistura química entre os magmas. Com base nos dados geoquímicos é possível definir que o magmatismo máfico mostra afinidade tholeiítica, enquanto o magmatismo félsico é caracterizado por granitos do tipo-A. O GES apresenta uma fácies de bordo caracterizada por monzogranitos porfiríticos de matriz fina a média com alto teor de enclaves máficos. A porção central do maciço é composta por sieno a monzogranitos heterogranulares grossos ricos em quartzo e com baixo teor de minerais máficos. Uma fácies de sienogranitos equigranulares ocorre na porção centro-norte e representa a cúpula parcialmente preservada do maciço. A zonação textural e composicional observada foram geradas a partir do resfriamento de uma única câmara magmática. 0 posicionamento do granito foi controlado por uma fase cinemática extensional da Zona de Cisalhamento Dorsal de Canguçu que permitiu a ascensão dos magmas até sua estabilização em níveis superiores da crosta. Os dados obtidos sugerem que a geração do GES ocorreu no período pós-colisional da orogênese Dom Feliciano, associada à fusão parcial de uma crosta granulítica, promovida pelo aumento do gradiente geotérmico devido ao magmatismo máfico. As condições de alta temperatura do evento magmático permitiram, em estágio precoce da cristalização, a mistura química entre os magmas félsico e máfico e a geração de tipos híbridos. Durante o processo da cristalização, entretanto, a viscosidade e a densidade dos magmas são modificadas, favorecendo o desenvolvimento de estruturas geradas pela mistura física. Palavras-chave. Cinturão Dom Feliciano, Batólito Pelotas, Suíte Encruzilhada do Sul, magmatismo tholeí́tico pós-colisional, granito tipo-A, mistura de magmas.
\end{abstract}

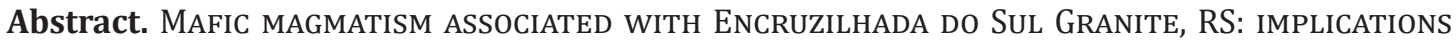

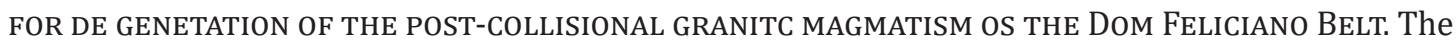
integration of geological mapping with petrographic and geochemical studies allowed the characterization of petrological evolution of the Encruzilhada do Sul Granite (ESG). This pluton occurs in the northern part of the Pelotas Batholith, eastern portion of the Dom Feliciano Belt. In the interior of the ESG small bodies of diorites and zones rich in mafic enclaves occur, representing an interaction of physical mixture between the acid and basic magmas. Granite facies with high content of mafic minerals and intermediate to acid composition are interpreted as hybrid rocks and related to the chemical mixture between the magmas. Based on the geochemical data, it is possible to define that mafic magmatism shows tholeiitic affinity, while felsic magmatism is characterized by A-type granites. The ESG presents an outer facies characterized by porphyritic monzo- to granodiorites of fine to medium matrix with high content of mafic enclaves. The central portion of the pluton is composed of thick heterogranular sieno to monzogranites rich in quartz and with low content of mafic minerals. A facies of equigranular sienogranites occurs in the center-north portion and represents the 
partially preserved cupola of the massif. Based on geochemical data, it is possible to define that the mafic magmatism shows tholeiitic affinity, whereas the felsic magmatism is characterized by A-type granites. The emplacement of the granite was controlled by an extensional kinematic phase related to the regional Dorsal do Canguçu Shear Zone, which allowed the rise of magmas up to higher levels of the crust. The data suggest that the generation of the ESG took place in the post-collisional period of Dom Feliciano orogeny and was associated with partial melting of a granulite crust promoted by increasing of the geothermal gradient due to the mafic magmatism. The high temperature conditions of the magmatic event allowed the chemical mixing between felsic and mafic magmas and the generation of hybrid types during an early stage of crystallization. The evolution of crystallization modified the viscosity and density of these magmas and imply on the development of mingling structures.

Keywords. Dom Feliciano Belt, Pelotas Batholith, Encruzilhada do Sul Suite, tholeiitic post-collisional magmatism, A-type granitoids, magma mixing.

\section{Introdução}

A presença de rochas ígneas máficas associadas ao magmatismo granítico é frequente em suítes e complexos graníticos expostos nos grandes batólitos vinculados a cinturões orogênicos como os batólitos Costeiro (Peru), Peninsular Ranges, Sierra Nevada e White Mountains (EUA), entre outros (Cobbing \& Pitcher, 1972; Atherton et al., 1979; Vernon, 1983, 1986; Eby et al., 1992; Pitcher, 1993; Chappell, 1996). Na porção sul da Província Mantiqueira o magmatismo máfico também foi descrito como um importante componente relacionado ao magmatismo granítico que constitui os batólitos Pelotas, Florianópolis e Aiguá (Bitencourt \& Nardi, 1993, 2000; Philipp et al., 2000, 2003; Philipp \& Machado, 2005; Oyhantçabal et al., 2007; Bitencourt et al., 2008).

Na região sul do Brasil e no Uruguai, o desenvolvimento do Ciclo Orogênico Brasiliano está representado pelo Cinturão Dom Feliciano (CDF), um orógeno alongado segundo a direção NE-SW, situado entre os crátons Rio de La Plata e Kalahari. Este processo envolveu intensa movimentação tectônica com regimes de subducção de crosta oceânica, colisões continentais e eventos de deformação crustal tardi a pós-colisionais com intenso magmatismo associado. O CDF é constituído no Rio Grande do Sul pelos Terrenos São Gabriel e Tijucas e pelo Batólito Pelotas. Estas unidades estão limitadas por zonas de cisalhamento dúcteis e encontram-se parcialmente recobertas pelas rochas sedimentares e vulcânicas da Bacia do Camaquã. A evolução final do cinturão ocasionou a formação do Batólito Pelotas, constituindo diversas suítes graníticas (Philipp et al., 2000; Philipp \& Machado, 2005). A construção do batólito ocorreu entre 650 e $550 \mathrm{Ma}$, com início relacionado ao metamorfismo colisional, e principalmente durante o período tardi a pós-colisional (Philipp et al., 2000, 2003, 2016a; Bitencourt \& Nardi, 2000; Koester et al., 2001; Frantz et al., 2003).

A geração e o posicionamento das suítes graníticas estão relacionados com as movimentações das zonas de cisalhamento dúcteis dispostas ao longo do Batólito Pelotas. Estas zonas estão dispostas em um padrão anastomosado de direção NE-SW, apresentam alto ângulo de mergulho, com movimentação oblíqua e transcorrente, e cinemática dominantemente sinistral (Fernandes et al., 1992a; Bitencourt \& Nardi, 1993, 2000; Philipp et al., 1993, 2003). 0 aumento do gradiente geotérmico relacionado ao pico do metamorfismo colisional e o alívio de pressão relacionado às fases de movimentação das zonas de cisalhamento dúcteis promoveram diversos episódios de fusão parcial na base da crosta continental e no topo do manto. Os magmas máficos juvenis interagiram com as fusões crustais e constituíram os corpos dioríticos e gabróicos, enclaves máficos microgranulares, diques máficos sin-plutônicos e granitoides híbridos associados com as suítes graníticas (Philipp et al., 1993, 1998, 2000, 2003, 2007; Bitencourt \& Nardi, 2000; Nardi \& Bitencourt, 2007).

A Suíte Encruzilhada do Sul (SES) ocorre na porção nordeste do Batólito Pelotas e constitui um maciço granítico alongado na direção $\mathrm{N} 30^{\circ} \mathrm{E}$, com cerca de $55 \mathrm{~km}$ de comprimento e $35 \mathrm{~km}$ de largura. A suíte é composta principalmente pelo Granito Encruzilhada do Sul (GES), e pelas rochas máficas contemporâneas, como os corpos de dioritos e os enclaves máficos microgranulares, além das faixas dos granitoides híbridos. 0 objetivo deste trabalho é caracterizar a petrologia do magmatismo máfico 
associado ao GES, com base nos dados de campo, análise petrográfica e geoquímica, com ênfase no estudo dos processos de mistura química e física entre os magmas ácido e básico.

\section{2 Área, materiais e métodos}

\subsection{Geologia regional}

AO Escudo Sul-rio-grandense é composto por associações de rochas metamórficas, ígneas e sedimentares dispostas em um complexo arranjo tectônico e estratigráfico, constituindo duas unidades principais: (i) o Terreno Taquarembó (TT) e (ii) o Cinturão Dom Feliciano (CDF) (Chemale Jr., 2000; Saalmann et al., 2010; Philipp et al., 2016b). O TT é um fragmento pertencente a uma unidade maior denominada Microcontinente ou Terreno Nico Perez, e representa o embasamento do CDF (Oyhantçabal et al., 2011; Rapela et al., 2011; Philipp et al., 2016b). O CDF é constituído pelos Terrenos São Gabriel, Tijucas e Punta del Este, e pelos Batólitos Florianópolis, Pelotas e Aiguá. Estas unidades caracterizam um cinturão com uma longa e complexa evolução, envolvendo as orogêneses Passinho (900-860 Ma), São Gabriel (770-680 Ma) e Dom Feliciano (650-540 Ma) (Chemale Jr., 2000; Hartmann et al., 2007; Philipp et al., 2016b) (Fig. 1).

No Rio Grande do Sul, o embasamento do CDF está preservado nos complexos ortognáissicos de idade paleoproterozoica Santa Maria Chico, Encantadas, Arroio dos Ratos e Vigia (Fernandes et al., 1992a, 1992b; Chemale Jr., 2000; Hartmann et al., 2007; Philipp et al., 2008, 2016a, 2016b;

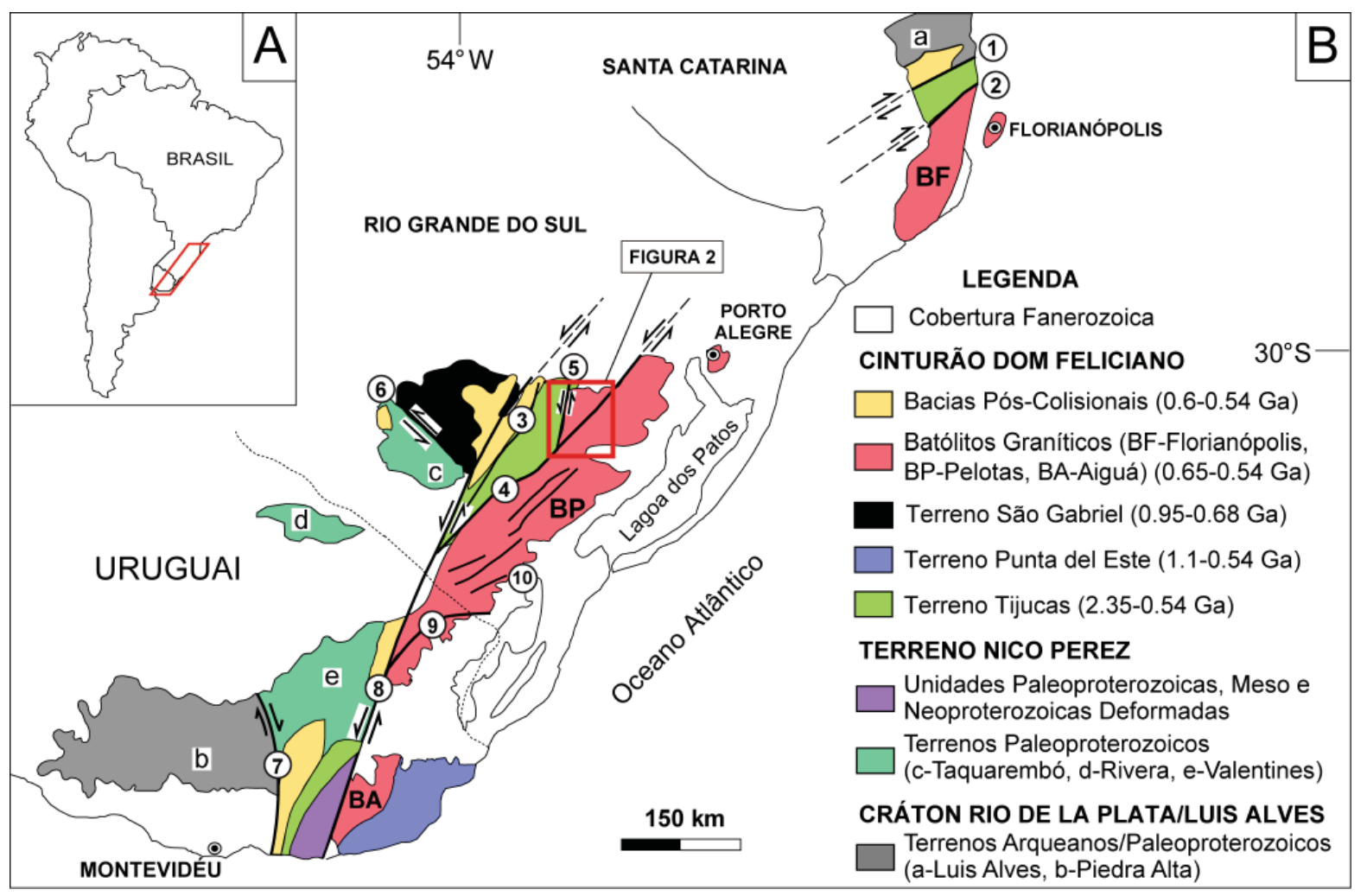

Figura 1. Mapa de localização do CDF no contexto tectônico da porção sul da América do Sul (modificado de Oyhantçabal et al., 2009, Rapela et al., 2011, Philipp et al., 2013, 2016b). A) Localização do CDF; B) Principais unidades geotectônicas do CDF e do seu embasamento. A área de estudo está destacada pelo retângulo vermelho. Ainda estão indicadas as principais zonas de cisalhamento: 1) Itajaí-Perimbó, 2) Major Gercino, 3) Caçapava do Sul, 4) Dorsal de Canguçu, 5) Passo dos Marinheiros, 6) Ibaré, 7) Sarandí del Yí, 8) Sierra Ballena, 9) Laguna Rocha, 10) Arroio Grande.

Figure 1. Map of the Dom Feliciano Belt (DFB) location in the tectonic context of the southern portion of South America (modified from Oyhantçabal et al., 2009; Rapela et al., 2011; Philipp et al., 2013, 2016b). A) Location of the DFB in South America; B) Main geotectonic units of the DFB and its basement. The study area is represented by the red rectangle. Still are indicate the main shear zones: 1) Itajaí-Perimbó, 2) Major Gercino, 3) Caçapava do Sul, 4) Dorsal de Canguçu, 5) Passo dos Marinheiros, 6) Ibaré, 7) Sarandí del Yí, 8) Sierra Ballena, 9) Laguna Rocha, 10) Arroio Grande. 
Gregory et al., 2015). A construção do CDF ao longo da margem continental do Terreno Nico Perez (TNP) foi precedida pela fragmentação do continente Rodínia a cerca de 1,0 Ga, que separou este terreno do Cráton Rio de La Plata (CRLP) através da abertura do Oceano Charrua (Philipp et al., 2016b). Ao leste do TNP, o Oceano Adamastor separava esta unidade do Cráton do Kalahari, situado na porção sul da África (Philipp et al., 2016b). 0 fechamento do Oceano Charrua e a convergência entre o CRLP e o TNP, entre 900 e $700 \mathrm{Ma}$, representaram o início da construção do CDF, com a formação de arcos intra-oceânicos na orogênese Passinho e de margem continental na orogênese São Gabriel, preservados no Terreno São Gabriel por meio de associações metavulcanosedimentares e metaplutônicas (Chemale Jr., 2000; Hartmann et al., 2007; Saalmann et al., 2010; Philipp et al., 2016b).

A evolução final do CDF envolveu a orogênese Dom Feliciano, culminando em um evento de metamorfismo regional associado à colisão dos crátons Rio de La Plata e Kalahari, entre 650 e 620 Ma (Chemale Jr. et al., 2011; Gregory et al., 2015; Philipp et al., 2016a, 2016b). A fusão do embasamento gnáissico durante o metamorfismo colisional foi responsável pela formação do Metagranito Quitéria e dos granitos peraluminosos da Suíte Cordilheira. A geração do Metagranito Quitéria está associada à interação de um magmatismo máfico com os ortognaisses do Complexo Arroio dos Ratos, enquanto os granitos da Suíte Cordilheira são relacionados à fusão parcial dos gnaisses pelíticos do Complexo Várzea do Capivarita (Koester et al., 2001; Philipp et al., 2013, 2016a). Após o pico do metamorfismo colisional, entre 650 e $620 \mathrm{Ma}$, uma intensa granitogênese de caráter tardi-colisional teve sequência e compreende os granitóides do Complexo Pinheiro Machado e da Suíte Viamão (Philipp et al., 1998, 2000, 2003, 2007; Bitencourt \& Nardi, 2000; Philipp \& Machado, 2005). A evolução final do batólito, entre 610 e 550 Ma, está relacionada à geração das suítes graníticas de caráter pós-colisional, incluindo as suítes Erval, Piquiri, Encruzilhada do Sul e Dom Feliciano.

O Batólito Pelotas (BP) tem forma alongada segundo a direção N40oE, com cerca de 370 km de comprimento e largura variando entre 110 e 70 $\mathrm{km}$. Apresenta continuidade para norte em Santa Catarina, constituindo o Batólito Florianópolis, e para o sul, no Uruguai, compondo o Batólito Aiguá (Philipp et al., 2000, 2007; Oyhantçabal et al., 2007; Bitencourt et al., 2008). A geração do BP foi consequência de distintos processos tectônicos, tais como a subducção de litosfera oceânica em margem continental espessa (Fragoso Cesar et al., 1986; Figueiredo et al., 1990; Philipp, 1990; Philipp et al., 1993, 2000), colisão entre continentes (Hartmann et al., 2000; Philipp \& Machado, 2001; Philipp et al., 2016b) e uma evolução em ambiente pós-colisional (Bitencourt \& Nardi, 2000; Philipp et al., 2000; Nardi \& Bitencourt, 2007).

A definição estratigráfica das unidades da região de Encruzilhada do Sul iniciou com os mapeamentos regionais realizados por Tessari \& Picada (1966), Picada \& Tessari (1970) e Frantz et al. (1984). Os estudos realizados por Vasquez (1997) e Bitencourt et al. (1993) investigaram a composição geoquímica e isotópica dos magmas graníticos e caracterizaram os processos de mistura com os magmas máficos. Philipp \& Campos (2005) avaliaram a variação petrográfica e a zonação faciológica do Granito Encruzilhada do Sul (GES) e suas consequências no aproveitamento do granito como rocha ornamental. O reconhecimento de fácies foi ressaltado por Tessari \& Picada (1966) que destacam as ocorrências pontuais de greisens com cassiterita, wolframita e fluorita nas fácies finas e pegmatóides do granito, na região de Pinheiros (Minas Sanga Negra e Cerro da Árvore).

Os granitos da SES estão em contato tectônico a leste com os granitos peraluminosos da Suíte Cordilheira (Koester et al., 2001), constituída pelos granitos Arroio Francisquinho e Cordilheira, com idades U-Pb SHRIMP em zircão de $634 \pm 6 \mathrm{Ma}$ e $625 \pm 6 \mathrm{Ma}$, respectivamente (Frantz et al., 2003) (Fig. 2). 0 contato da SES com os metassedimentos do Complexo Porongos a oeste é tectônico, definido pela Zona de Cisalhamento Passo dos Marinheiros. Este contato é afetado pela movimentação da zona de cisalhamento transcorrente de cinemática sinistral, que desloca o corpo granítico e a Zona de Cisalhamento Dorsal de Canguçu por cerca de 130 km (Picada, 1971). Ao norte, os granitos da SES são recobertos por rochas sedimentares da Formação 


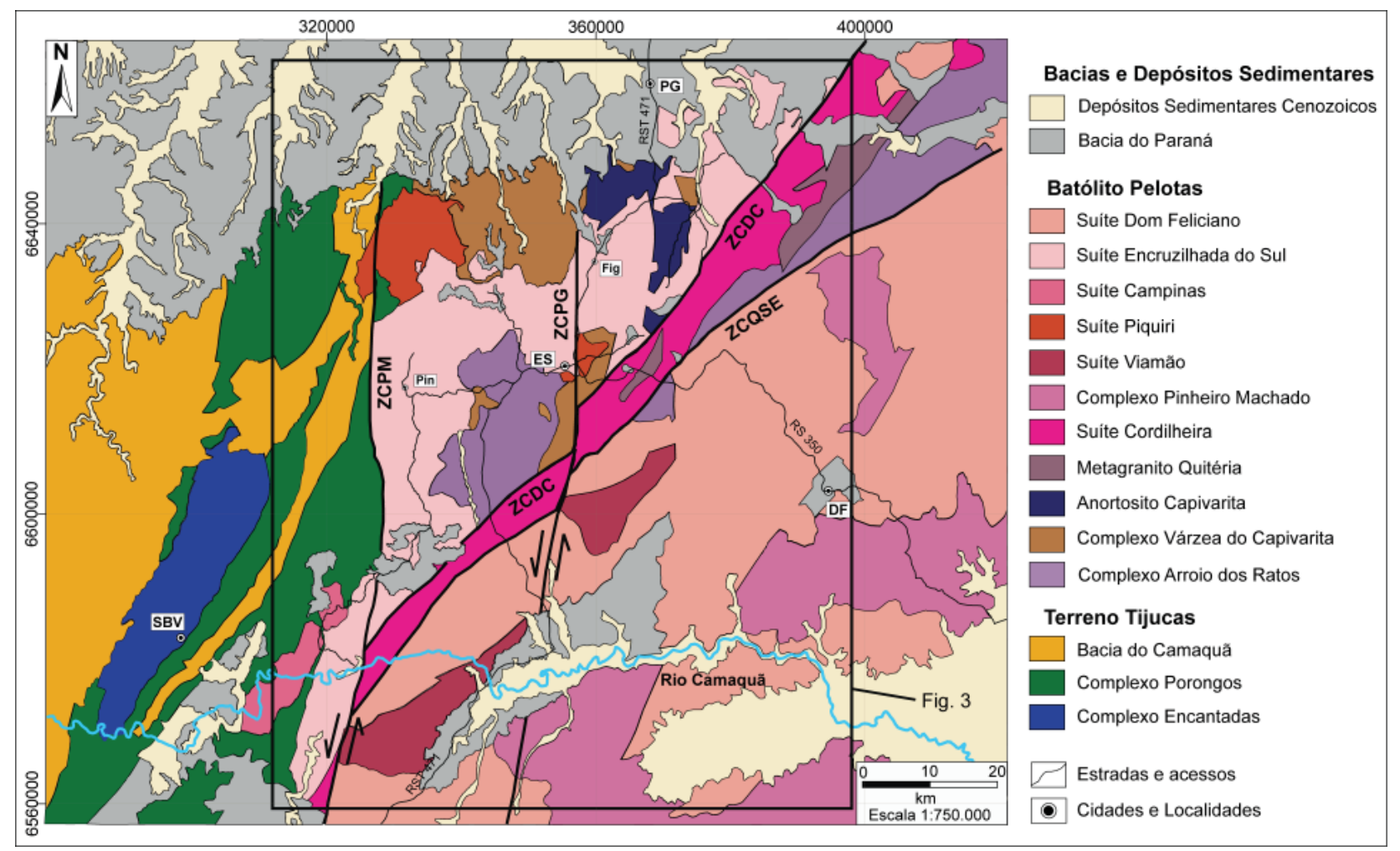

Figura 2. Contexto geológico da SES (modificado de Wildner et al., 2007). Zonas de cisalhamento transcorrentes: ZCDC- Dorsal de Canguçu, ZCPM- Passo dos Marinheiros, ZCPG- Pântano Grande, ZCQSE- Quitéria-Serra do Erval. Cidades: ES- Encruzilhada do Sul, DF- Dom Feliciano, PG- Pântano Grande, SBV- Santana da Boa Vista. Vilas: Pin- Pinheiros, Fig- Figueiras.

Figure 2. Geological context of the Encruzilhada do Sul Suite (modified from Wildner et al., 2007). Transcurrent shear zones: ZCDCDorsal de Canguçu, ZCPM- Passo dos Marinheiros, ZCPG- Pântano Grande, ZCQSE- Quitéria-Serra do Erval. Cities: ES- Encruzilhada do Sul, DF- Dom Feliciano, PG- Pântano Grande, SBV-Santana da Boa Vista. Villas: Pin- Pinheiros, Fig- Figueiras.

Rio Bonito, base do Grupo Guatá, pertencentes à Bacia do Paraná.

As rochas encaixantes da SES são constituídas pelos gnaisses dos complexos Arroio dos Ratos e Várzea do Capivarita, e pelo Meta-anortosito Capivarita (Fig. 2). Estas unidades foram afetadas pelo metamorfismo colisional entre 650 e $620 \mathrm{Ma}$, em um regime tectônico compressivo associado ao desenvolvimento de zonas de cisalhamento oblíquas nas porções profundas da crosta, sob condições metamórficas da Fácies Granulito (650 a $900^{\circ} \mathrm{C}$ ) e pressões intermediárias (8 a 10 Kbares) (Philipp et al., 2013, 2016a). 0 Complexo Arroio dos Ratos foi descrito por Gregory et al. (2011), na região de Quitéria, como um conjunto de gnaisses tonalíticos e granodioríticos com diques sin-plutônicos intrusivos de metatonalitos a metadioritos, ambos de idade Paleoproterozoica, originados em ambiente de arco continental. 0 Complexo Várzea do Capivarita é composto por gnaisses pelíticos, subordinadamente gnaisses cálcico-silicáticos, mármores, gnaisses quartzo-feldspáticos e raros quartzitos (Philipp et al., 2013; Bom et al., 2014).
No metamorfismo orogênico, os gnaisses pelíticos foram migmatizados com a geração de leucogranitos peraluminosos posicionados em concordância com o bandamento dos gnaisses (Philipp et al., 2016a). Entre estes corpos, se destaca o Granito Butiá, um silimanita-muscovita-biotita leucogranito equigranular, com idade $\mathrm{U}-\mathrm{Pb}$ em monazita de $629 \pm 28$ Ma (Bitencourt et al., 2015). O Meta-anortosito Capivarita compreende três corpos de anortositos, com presença subordinada de anfibolitos com idades de cristalização U-Pb em zircão de $1573 \pm 21$ Ma (Chemale Jr. et al., 2011).

Os mapeamentos em escala 1:25.000 desenvolvidos pela UFRGS $(2008,2009,2010,2011)$ indicaram que os granitos da SES contêm megaxenólitos, roof pendants e xenólitos menores, com dimensões variáveis de metros a centenas de metros, dos complexos Arroio dos Ratos e Várzea do Capivarita, e do Meta-anortosito Capivarita. Registra-se uma margem resfriada caracterizada pela ocorrência de granitos da fácies equigranular fina no contato com as rochas gnáissicas do embasamento. 
Nas porções centrais do maciço, assim como ao norte e ao sul, o granito é intrusivo nos gnaisses pelíticos e calci-silicáticos do Complexo Várzea do Capivarita e nos ortognaisses do Complexo Arroio dos Ratos. Na sua porção nordeste, o granito é intrusivo no Meta-anortosito Capivarita (Philipp \& Campos, 2005; Philipp et al., 2010; Martil et al., 2011). Em todas estas unidades a intrusão causou efeitos termais, caracterizados por um amplo retrometamorfismo.

O magmatismo pós-colisional de natureza alcalina ultra-potássica está representado pelos sienitos da Suíte Piquiri (Fig. 2), com idades $\mathrm{Pb}$ -Pb TIMS de $611 \pm 3$ Ma e $612 \pm 3$ Ma (Philipp et al., 2002). A ocorrência de fragmentos angulosos de sienitos no GES e de diques graníticos cortando a referida unidade atestam o caráter intrusivo do granito (Bitencourt et al., 1993; UFRGS, 2008, 2009).

A cristalização da SES ocorreu no período tardi a pós-colisional, com idades pelo método $\mathrm{Rb}$ - $\mathrm{Sr}$ (isócrona em rocha total e minerais separados) de $582 \pm 17$ Ma (Vasquez, 1997) e U-Pb em zircão (TIMS) de $594 \pm 5$ Ma (Babinski et al., 1997). A razão inicial de ${ }^{87} \mathrm{Sr} /{ }^{86} \mathrm{Sr}$ obtida para o Granito Encruzilhada do Sul apresentou um valor de 0,71152, indicando a participação de fontes crustais para o magmatismo granítico (Babinski et al., 1997). Os autores confirmaram esta fonte com a composição isotópica de $\mathrm{Sm}-\mathrm{Nd}$, onde o granito apresentou um valor de $\varepsilon_{\mathrm{Nd}(\mathrm{t})}$ de $-15,5$, com uma idade $\mathrm{T}_{\mathrm{DM}}$ de 2,08 Ga.

As relações estruturais e geocronológicas indicam que o posicionamento dos granitos da SES foi posterior a movimentação principal da ZCDC (Bitencourt et al., 1993; Philipp et al., 2003; Philipp \& Machado, 2005). Nas proximidades da ZCDC, o GES registra em áreas muito localizadas, uma deformação no estado dúctil-rúptil, com o desenvolvimento de estruturas protomiloníticas concordantes a orientação da zona de cisalhamento (UFRGS, 2010, 2011). A formação das zonas de cisalhamento Passo dos Marinheiros e Pântano Grande é posterior ao posicionamento da SES e originaram nos granitos a formação de brechas, cataclasitos e ultracataclasitos, além de intenso fraturamento.

\subsection{Materiais e métodos}

Este trabalho tem como base o mapeamento geológico com ênfase na geologia dos corpos dioríticos, enclaves máficos microgranulares e das faixas de granitoides híbridos. Os levantamentos de campo incluíram a coleta de amostras para análises petrográficas e geoquímicas.

O mapa geológico na escala 1:25.000 foi obtido a partir da integração dos trabalhos de campo com os mapas disponibilizados por Ramgrab et al. (1997), Vasquez (1997), Ventzke (2007), Wildner et al. (2007) e UFRGS $(2008,2009,2010,2011)$.

As lâminas delgadas foram confeccionadas no Laboratório de Apoio Analítico e Preparação das Amostras, no Centro de Estudos em Petrologia e Geoquímica do Instituto de Geociências da UFRGS. Foram efetuadas análises petrográficas em 18 amostras de dioritos e enclaves máficos microgranulares, e 22 amostras de rochas graníticas. A classificação petrográfica das amostras foi feita com base na análise modal, obtida através da contagem de cerca de 500 pontos em chapas cortadas. Para a distinção dos feldspatos, a seção cortada da amostra foi imersa por 60 s em uma solução de ácido fluorídrico. Após secagem, a amostra foi imersa por 60 s em uma solução de cobaltinitrito de sódio, obtendo a cor amarela para o K-feldspato e a cor branca para o plagioclásio. Normalizando os valores obtidos de quartzo, K-feldspato e plagioclásio as amostras foram representadas no diagrama QAP de Streckeisen (1976). A descrição das feições de mistura de magmas teve como base os conceitos de Hibbard (1995).

A composição química de 27 amostras de rochas máficas e granitoides híbridos foi determinada no Acme Analítica Laboratórios Ltda, na cidade de Aparecida de Goiânia, Goiás. As análises dos elementos maiores foram obtidas por ICP-ES (Inductively Coupled Plasma-Emission Spectrometry), com limite da detecção de 0,01\%. Os elementos traços e os terras raras foram determinados por ICP-MS (Inductively Coupled Plasma-Mass Spectrometry), com limite de detecção entre 0,005 e 2 ppm. Para os estudos geoquímicos foram incluídas no banco de dados 58 análises de rochas graníticas e granitoides híbridos obtidas por Vasquez (1997). 


\section{Resultados}

A integração dos dados de campo e petrográficos permitiu reconhecer no GES uma zonação composicional e textural definida por fácies petrográficas dispostas de modo concêntrico e concordante à forma do maciço. Foram reconhecidas quatro fácies principais: (1) porfirítica de matriz fina a média, nos bordos nordeste e sudoeste, (2) porfirítica a heterogranular média a grossa na porção central, (3) equigranular média a grossa na porção central e leste do maciço e (4) equigranular fina a média na porção central (Fig. 3). No interior das fácies ainda foram individualizados granitoides híbridos, dioritos e zonas ricas em enclaves máficos microgranulares. Nestas áreas observa-se a interação química (mixing) e física (mingling) entre os magmas máficos e félsicos, indicando a contemporaneidade de ambos. Nos bordos do maciço, a fácies porfirítica apresenta os corpos mais expres- sivos de dioritos e também as faixas mais desenvolvidas de granitoides híbridos. Nos granitos porfiríticos a heterogranulares, a ocorrência de rochas máficas é menos expressiva e dispersa, enquanto nas fácies equigranulares é restrita e/ou ausente.

\subsection{Petrografia}

O GES é constituído por monzogranitos a sienogranitos porfiríticos e heterogranulares e, subordinadamente, por sienogranitos equigranulares, com ocorrência comum de dioritos, enclaves máficos microgranulares e faixas métricas de granitoides híbridos, incluindo termos de composição monzogranítica, granodiorítica e quartzo-monzodiorítica. Estes granitoides apresentam textura equigranular média e teor mais elevado de minerais máficos que os termos graníticos, variando entre 10 e $35 \%$ (Fig. 4).

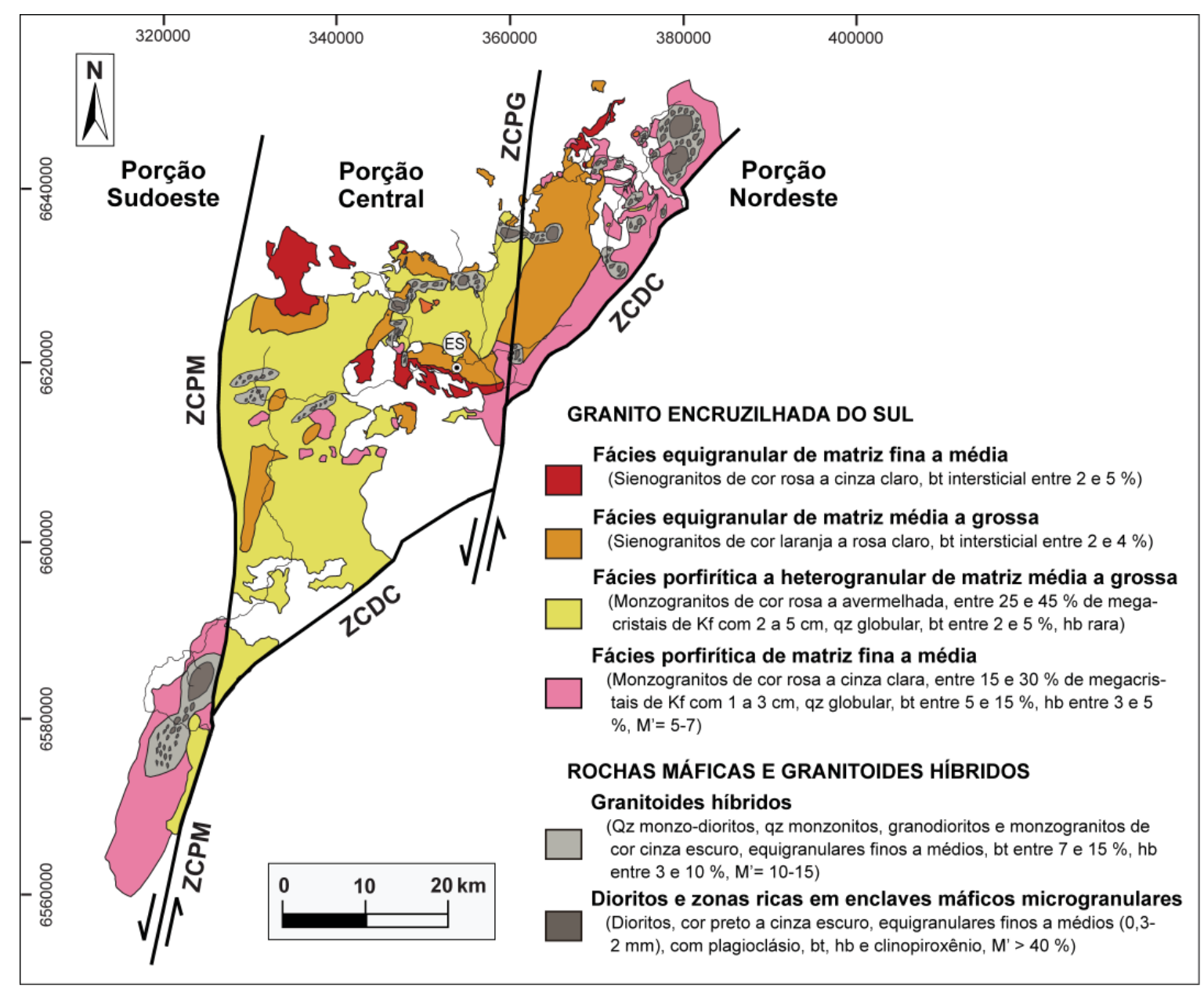

Figura 3. Mapa geológico da Suíte Encruzilhada do Sul (Modificado de Vasquez, 1997; Ventzke, 2007; Wildner et al., 2007 e UFRGS, 2008, 2009, 2010, 2011).

Figure 3. Geological map of the Encruzilhada do Sul Suite (Modified from Vasquez, 1997; Ventzke, 2007; Wildner et al., 2007 and UFRGS, 2008, 2009, 2010, 2011). 


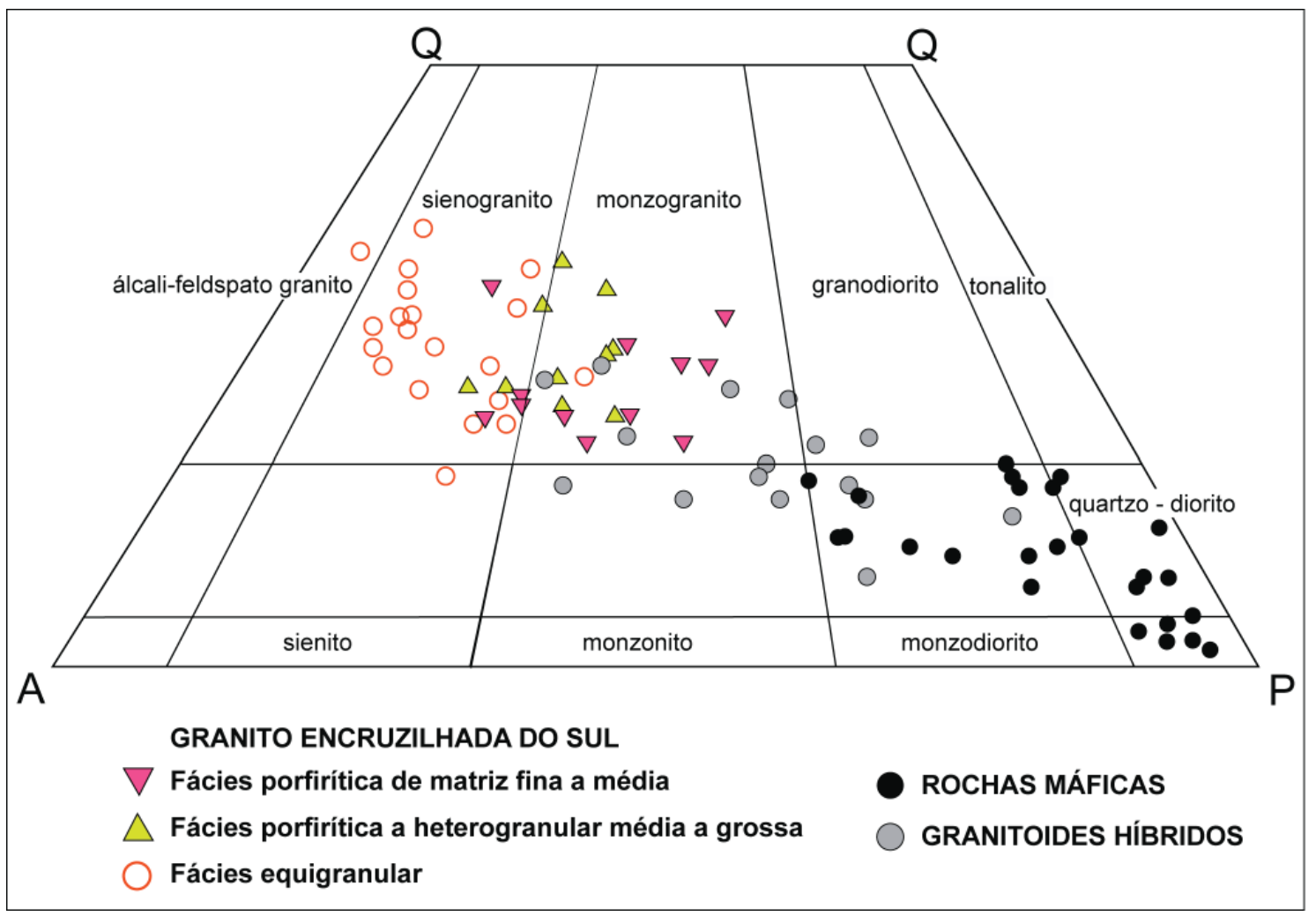

Figura 4. Classificação modal das amostras das fácies graníticas, granitoides híbridos e das rochas máficas da Suíte Encruzilhada do Sul. Legenda: Q- quartzo, A- feldspato alcalino, P- plagioclásio.

Figure 4. Modal classification of samples of granite facies, hybrid granitoids and mafic rocks of Encruzilhada do Sul Suite. Subtitle: Q- quartz, A- alkaline feldspar, P- plagioclase.

Os contatos entre as fácies porfiríticas e heterogranulares são interlobados e gradacionais, enquanto as fácies equigranulares são intrusivas nas demais. Os granitos são caracterizados por elevadas porcentagens de K-feldspato e quartzo, com teores variáveis de plagioclásio e minerais máficos (entre 2 e $5 \%$ ). Os cristais de quartzo apresentam forma globular e/ou hexagonal. Os minerais máficos ocorrem na forma de agregados de biotita, com presença subordinada de hornblenda.

\subsubsection{Fácies porfirítica}

A fácies porfirítica de matriz fina a média constitui a porção de bordo do GES, disposta como uma faixa alongada envolvendo o maciço. É a fácies que apresenta maior variação composicional e textural, com predomínio de biotita monzogranitos, com variado teor de minerais máficos e zonas ricas em enclaves máficos e dioritos. Em geral apresentam estrutura maciça, mas podem apresentar uma foliação de fluxo magmático com disposição irregular e definida pelo alinhamento de megacristais de K-feldspato e de agregados de biotita. 0 granito tem cor cinza e pontuações rosadas e alaranjadas, com textura porfirítica caracterizada por megacristais de K-feldspato com tamanhos em geral, entre $1 \mathrm{e} 2 \mathrm{~cm}$, podendo atingir até $4 \mathrm{~cm}$ (Fig. 5A). Os megacristais têm formas prismáticas e alongadas, são euédricos a subédricos e variam entre 15 e $30 \%$ do volume da rocha. Mostram inclusões de apatita, plagioclásio e quartzo. A matriz é equigranular hipidiomórfica fina a média $(0,3$ a 3,5 mm), constituída por plagioclásio (25 a $35 \%$ ), quartzo (25 a $30 \%$ ), K-feldspato (15 a $25 \%$ ), agregados intersticiais de biotita (5 a $15 \%$ ) e hornblenda (3 a $5 \%$ ), com zircão, apatita, alanita, magnetita e titanita como minerais acessórios.

Os dioritos que ocorrem nesta fácies apresentam dezenas de metros de extensão. Possuem cor preta e textura equigranular hipidiomórfica fina a média, constituída por plagioclásio, hornblenda, biotita e pouco quartzo, com augita e K-feldspato subordinados (Fig. 5B). Os enclaves máficos microgranulares são arredondados, com dimensões entre 15 e até $40 \mathrm{~cm}$. Os contatos entre os enclaves máficos e os dioritos são curvilíneos e bem definidos, ocorrendo porções com contatos interlobados e pouco definidos, indicando a pouca diferença de viscosidade entre os magmas (Fig. 
5C). Os corpos máficos estão envoltos por faixas métricas de granitoides híbridos de cor cinza escura a cinza clara, com textura equigranular hipidiomórfica fina a média, definida por plagioclásio, K-feldspato e quartzo, com variável percentagem de biotita e hornblenda (entre 10 e $35 \%$ ).

Nas proximidades da ZCDC, os granitos apresentam localizadamente, feições de deformação dúctil, gerando faixas protomiloníticas centimétricas a métricas. Nestas porções, os porfiroclastos de K-feldspato apresentam extinção ondulante, fraturas com formação de subgrãos e bordos parcialmente recristalizados. 0 plagioclásio mostra encurvamento de maclas e está fraturado com formação de subgrãos com limites interlobados. A biotita mostra encurvamento das clivagens e recristalização parcial para agregados de novos cristais finos alinhados segundo à foliação. 0 quartzo apresenta forte extinção ondulante com formação de subgrãos com limites serrilhados envoltos por agregados finos recristalizados com textura granoblástica. Observam-se subgrãos equidimensionais com maclas do tipo tabuleiro de xadrez, indicando uma deformação de elevada temperatura durante o estágio de resfriamento.

\subsubsection{Fácies porfirítica a heterogranular média a grossa}

Esta fácies é a mais expressiva do GES. A cor do granito inalterado é rosa a avermelhada e bege quando alterado, com pontuações pretas, castanhas e brancas. A composição predominante é monzogranítica, com sienogranitos subordinados. A mineralogia essencial é composta por K-feldspato ( 45 a $55 \%$ ), quartzo ( 25 a $30 \%$ ), plagioclásio (15 a 20 \%) e biotita (3 a 5 \%), com zircão, apatita, alanita, magnetita e titanita como minerais acessórios. A estrutura é maciça, porém há porções localizadas com uma foliação de fluxo definida pela orientação dimensional dos megacristais de K-feldspato e de agregados de biotita. Nestas zonas o granito pode apresentar estruturas geradas pelo fluxo magmático, como a elevada concentração de megacristais de K-feldspato, gerando cumulatos com formas alongadas e espessuras centimétricas, acompanhados por schlieren irregulares de biotita e hornblenda.
A textura principal é heterogranular hipidiomórfica grossa (3 a $35 \mathrm{~mm}$ ), constituída de uma trama dominada por K-feldspato com espaços intersticiais contendo plagioclásio, quartzo globular e biotita (Fig. 5D). Os megacristais de K-feldspato do tipo Microclínio e Ortoclásio têm forma prismática, são euédricos a subédricos e variam de 2 a 4 $\mathrm{cm}$, podendo chegar a $7 \mathrm{~cm}$. Os megacristais têm textura meso e micropertítica marcada pela exsolução de finos filetes de albita, e zonação concêntrica com linhas de crescimentos marcadas por trilhas de inclusões de apatita, plagioclásio, quartzo e biotita.

Nas proximidades do contato com os gnaisses do embasamento, são encontrados xenólitos de dimensões centimétricas a métricas do Complexo Várzea do Capivarita, caraterizados por silimanita-granada-biotita gnaisses, silimanita-cordieritagranada-biotita gnaisses e diopsídio-hornblenda -plagioclásio-quartzo gnaisses. Nestas porções, a variação do conteúdo de biotita no granito é grande, e pode apresentar bandamento irregular e descontínuo, milimétrico a centimétrico definido por schlieren de biotita.

Os dioritos constituem corpos métricos $11 \mathrm{a}$ $4 \mathrm{~m}$ ) associados aos enclaves máficos, que mostram formas globulares até irregulares. Nos enclaves, as composições são variáveis de quartzo-dioríticas, tonalíticas e granodioríticas com conteúdo de minerais máficos mais elevados que os do granito, entre 7 e 35 \% (Fig. 5E). A textura é equigranular fina a média, composta por uma trama de plagioclásio, hornblenda e biotita. No interior dos enclaves ocorrem xenocristais de K-feldspato e quartzo corroídos, com terminações arredondadas, envoltos por franjas finas de biotita e/ou hornblenda e por plagioclásio, caracterizando respectivamente as texturas ocelar e rapakivi (Fig. 5F).

\subsubsection{Fácies equigranular média a grossa}

Esta fácies ocorre nas porções central e leste do GES. É caracterizada por sienogranitos de cor laranja a rosa clara, com pontuações pretas, castanhas e brancas (Fig. 6A). Os granitos mostram grande homogeneidade composicional e textural, com rara ocorrência de enclaves máficos. A textura é equigranular hipidiomórfica média a grossa $(2$ a 

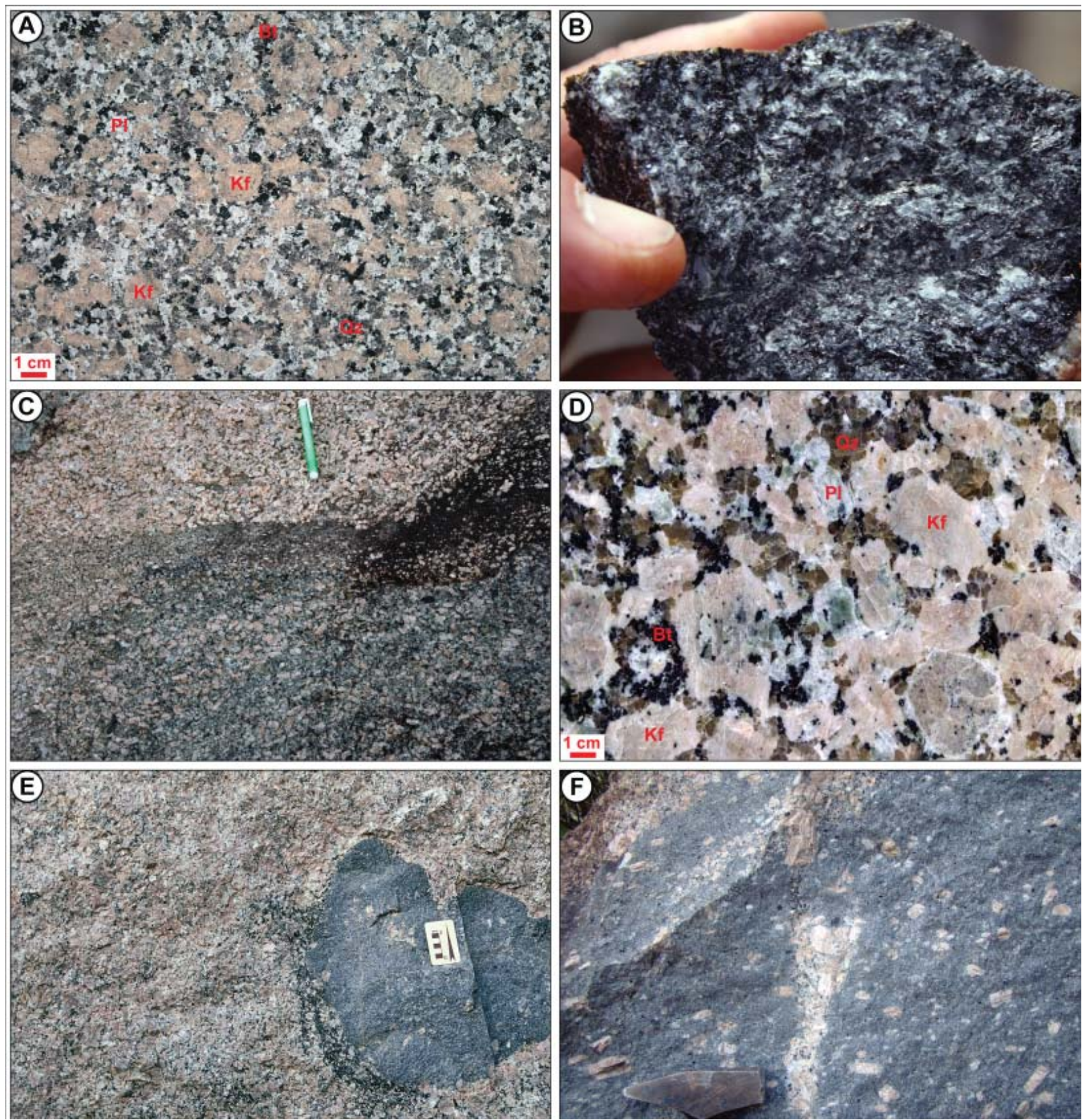

Figura 5. Aspectos macroscópicos das unidades da Suíte Encruzilhada do Sul. A) Monzogranito da fácies porfirítica do bordo nordeste, com megacristais de K-feldspato (Kf) envoltos por uma matriz composta por plagioclásio (Pl), biotita (Bt) e quartzo (Qz) globular; B) Diorito da fácies porfirítica do bordo sudoeste; C) Contato interlobado entre monzogranito porfirítico (parte superior da foto) e um granito porfirítico híbrido, com elevada concentração de minerais máficos (parte inferior); D) Granito heterogranular da porção central, com cristais de K-feldspato (Kf), plagioclásio (Pl), agregados de quartzo (Qz) com forma globular e biotita (Bt); E) Enclave máfico em monzogranito heterogranular da porção central; F) Xenocristais de K-feldspato hospedados em enclave da porção central. Observar injeção do granito porfirítico com limites interlobados.

Figure 5. Macroscopic aspects of the units from Encruzilhada do Sul Suite. A) Porphyritic monzogranite from the northeast border, with K-feldspar (Kf) megacrysts surrounded by a matrix composed of plagioclase (Pl), biotite (Bt) and globular quartz (Qz); $B$ ) Diorite from the southwest border; C) Interlobated contact between porphyritic monzogranite (upper part of the photo) and hybrid porphyritic granite with high mafic minerals content (lower part); D) Heterogranular granite from the central portion, with K-feldspar (Kf) crystals, plagioclase (Pl), globular quartz (Qz) aggregates and biotite (Bt); E) Mafic enclave in heterogranular monzogranite from the central portion; F) Xenocrysts of $K$-feldspar hosted in the enclave from the central portion. Observe porphyritic monzogranite injection with interlobated contacts. 
$8 \mathrm{~mm}$ ), dominada por cristais de K-feldspato (50 a $60 \%$ ) e quartzo (30 a $35 \%$ ), com plagioclásio (10 a $15 \%$ ) e biotita ( 2 a 5 \%), e zircão, apatita, alanita, magnetita e titanita como minerais acessórios.

\subsubsection{Fácies equigranular fina a média}

Os granitos desta fácies ocorrem na porção centro-norte do maciço e são classificados como sienogranitos. As relações de contato com os granitos das outras fácies são intrusivas, embora também mostrem contatos gradacionais, sugerindo que estes representam as margens resfriadas das porções apicais de cúpula parcialmente preservada. A textura é equigranular fina a média $(0,2$ a 3 $\mathrm{mm}$ ), com textura porfirítica subordinada caracterizada por esparsos megacristais de K-feldspato (< $2 \%$ ) imersos em uma matriz hipidiomórfica constituída por K-feldspato (50 a $60 \%$ ), quartzo (30 a $40 \%$ ), plagioclásio (5 a $10 \%$ ) e biotita (2 a $5 \%$ ), com zircão, apatita, magnetita e titanita como minerais acessórios. Não foram identificados enclaves máficos microgranulares.

\subsubsection{Rochas máficas (dioritos, enclaves máficos microgranulares) e granitoides híbridos}

\section{Dioritos}

Os dioritos constituem corpos de formas arredondadas e alongadas segundo a direção NE-SW, com dimensões entre alguns metros a dezenas de metros. Os maiores corpos e a maior expressão destas rochas ocorrem nos granitos da fácies porfirítica de matriz fina a média, diminuindo acentuadamente sua presença nos granitos das porções mais centrais. As relações de contato com as rochas graníticas são caracterizadas pelas formas curvilíneas a interlobadas e interdigitadas, evidenciando contemporaneidade dos magmas como misturas heterogêneas. Os dioritos estão envoltos por zonas métricas de granitoides híbridos de composição variável entre tonalitos, granodioritos e quartzo-monzodioritos, com texturas equigranulares e elevado teor de minerais máficos. Injeções graníticas a pegmatóides no interior dos dioritos são comuns.

Os dioritos têm cor preta a cinza esverdeada, estrutura maciça e textura equigranular hipi- diomórfica fina a média $(0,3$ a $2 \mathrm{~mm})$ caracterizada por uma trama de cristais prismáticos equidimensionais de plagioclásio, agregados de hornblenda e biotita, com ocorrência subordinada de augita, Kfeldspato e quartzo. Variam composicionalmente para termos quartzo-monzodioríticos e quartzodioríticos. Zircão, apatita, magnetita, alanita e titanita constituem as fases acessórias (Fig. 6B).

0 plagioclásio é uma andesina, de forma prismática euédrica e com zonação normal definida por núcleos cálcicos alterados para epidoto, sericita e calcita. A hornblenda ocorre como agregados de cristais prismáticos, subédricos a euédricos, contendo inclusões de apatita e titanita. A biotita constitui agregados de cristais subédricos e também envolve os cristais de hornblenda. A augita apresenta formas equidimensionais com tamanhos entre 0,2 e $3 \mathrm{~mm}$. Por vezes, apresenta textura coronítica, sendo envolta por franjas de hornblenda, evidenciando o aumento da atividade de fluídos tardi-magmáticos e o resfriamento magmático. Xenocristais de K-feldspato e de quartzo ocorrem dispersos nos corpos máficos, comumente com formas arredondadas corroídas e/ou com textura "em peneira". A apatita tem forma prismática alongada e pode constituir até $1 \%$ da porcentagem modal. A titanita apresenta forma losangular, subédrica, com tamanhos entre 0,2 e 0,8 mm e constitui até $2 \%$ da porcentagem modal.

\section{Enclaves máficos microgranulares}

Os enclaves máficos ocorrem ao longo de todo o GES, entretanto, sua expressividade é nas porções sudoeste e nordeste, associada aos granitos da fácies porfirítica de matriz fina a média. Por consequência, a faixa de granitoides híbridos também os abrange. As composições dos enclaves variam entre dioríticas e quartzo-dioríticas. Têm cor preta a cinza escura, e textura equigranular hipidiomórfica fina $(0,1$ a $2 \mathrm{~mm})$ constituída por plagioclásio, hornblenda e biotita com baixos conteúdos de quartzo, augita e K-feldspato. Apresentam formas arredondadas, subarredondadas ou subangulosas, com dimensões de 10 a $40 \mathrm{~cm}$. Observa-se também corpos tabulares com cerca de 15 e 80 metros de extensão e entre 2 e 15 metros de largura. Estes corpos encontram-se parcialmente desmembrados pela ação do fluxo e de- 
monstram relações de mistura química (mixing) e física (mingling) com o magma granítico. Nas áreas de mistura química ocorrem zonas muito mais ricas em enclaves. Os enclaves apresentam limites curvilíneos e irregulares com contatos difusos e gradacionais, envoltos por granitoides híbridos de textura equigranular média, com conteúdo variável de minerais máficos. Nas zonas de mistura física os enclaves evidenciam limites curvilíneos a retilíneos bem definidos. 0 monzogranito porfirítico apresenta uma foliação magmática concordante com os limites dos corpos máficos tabulares e ao longo destes observam-se injeções do granito. Os contatos são curvilíneos e interlobados e a matriz do granito é mais fina. Os enclaves desmembrados estão envoltos pela foliação magmática do granito, na qual ocorre uma disposição concêntrica dos megacristais de K-feldspato.

Nos granitos da fácies porfirítica a heterogranular média a grossa, na porção central do maciço, a abrangência dos enclaves máficos e dos granitoides híbridos é mais restrita que na fácies porfirítica de matriz fina a média. Os enclaves em geral, encontram-se arredondados e subarredondados, entretanto ocorrem corpos tabulares descontínuos e constituídos por enclaves com dimensões entre 10 e $40 \mathrm{~cm}$ (Fig. 6C). As composições variam entre dioríticas, quartzo-dioríticas a quartzo-monzoníticas, ocorrendo ainda tonalitos, granodioritos e monzogranitos. A textura é equigranular hipidiomórfica fina $(0,2$ a $1 \mathrm{~mm})$, com microfenocristais esparsos de plagioclásio, dispersos em uma matriz composta por hornblenda e biotita, com baixos conteúdos de quartzo e K-feldspato (Figs. 6D e 6E). Os enclaves de microgranitos têm cor cinza clara e apresentam formas arredondadas e elípticas com dimensões entre 20 e $40 \mathrm{~cm}$.

0 plagioclásio ocorre como microfenocristais prismáticos, euédricos e subédricos, com tamanhos entre 1 e $3 \mathrm{~mm}$, apresentando zonação normal. 0 plagioclásio também forma aglomerados, caracterizando a textura synneusis. A hornblenda tem forma prismática, euédrica e subédrica, ocorrendo em agregados ou de modo intersticial. A augita constitui agregados de cristais prismáticos subédricos e comumente estão envoltos por hornblenda. A biotita é subédrica, com tamanhos entre 0,05 a $0,8 \mathrm{~mm}$. Por vezes ocorre como finas franjas envolvendo xenocristais de Kfeldspato e quartzo. 0 quartzo é amebóide e intersticial, variando entre 0,2 e $0,6 \mathrm{~mm}$. Os xenocristais de K-feldspato (microclínio) apresentam formas subarredondadas relacionadas a corrosão térmica pelo contato com o magma máfico de alta temperatura. Por vezes, os xenocristais de K-feldspato encontram-se envoltos por mantos finos de albita. Destaca-se a textura ocelar, caracterizada pelo envolvimento dos xenocristais de quartzo por franjas de microcristais de clinopiroxênio, hornblenda e/ ou biotita (Fig. 6F).

\section{Granitoides híbridos}

Os granitoides híbridos constituem faixas marginais ao redor dos dioritos ou de zonas muito ricas em enclaves máficos. Apresentam cor cinza clara a escura, com textura equigranular hipidiomórfica fina a média $(0,2$ a $4 \mathrm{~mm})$, comumente com conteúdo elevado de minerais máficos $(10$ e $35 \%$ ). De modo subordinado, apresentam textura porfirítica definida por megacristais de plagioclásio e K-feldspato, envoltos por uma matriz composta por plagioclásio, quartzo, hornblenda e biotita. A mistura homogênea dos magmas é caracterizada pelos contatos difusos e gradacionais entre os granitoides híbridos e os dioritos e/ou enclaves máficos.

Nas porções nordeste e central do maciço, os granitoides apresentam uma foliação magmática irregular, marcada pela orientação dos schlieren de biotita e hornblenda, por agregados ricos em megacristais de K-feldspato e pelo alongamento dos enclaves máficos.

O K-feldspato é do tipo Ortoclásio e o Microclínio, ambos micropertíticos, com forma prismática subédrica e tamanhos entre 2 e $10 \mathrm{~mm}$. 0 plagioclásio tem forma prismática subédrica, tamanhos entre 1 e 6 mm e mostra zonação normal e inversa, com as bordas e os núcleos desestabilizados e corroídos, caracterizando textura "em peneira". O quartzo mostra forma globular e hexagonal, com tamanhos entre 0,1 e 0,3 $\mathrm{mm}$. A hornblenda é o principal mineral máfico, tem forma prismática e subédrica, com tamanhos entre 0,2 e $2 \mathrm{~mm}$, ocorrendo como agregados ou de modo intersticial. A biotita ocorre como agregados de palhetas euédricas a subédricas, com tamanhos entre 0,1 a 

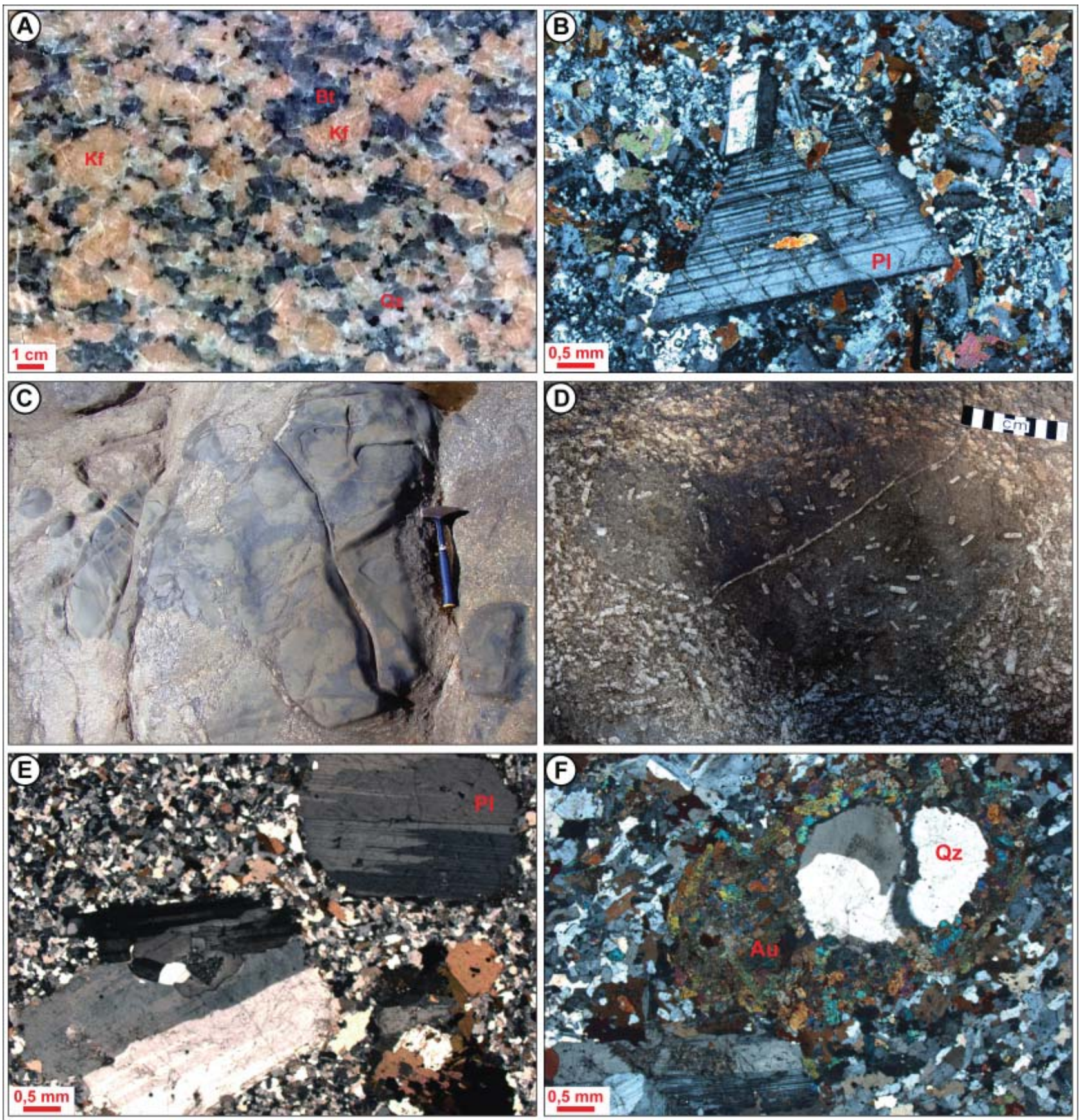

Figura 6. Aspectos macro e microscópicos do GES e das rochas máficas. A) Sienogranito equigranular da porção centro-leste; B) Fotomicrografia de diorito da porção sudoeste, com textura porfirítica definida por fenocristal de plagioclásio (Pl) e baixa porcentagem de quartzo (cor clara) disseminada na matriz; C) Enclaves máficos em monzogranito porfirítico da porção central; D) Enclave máfico da porção central, com fratura preenchida por material félsico e migração mecânica dos feldspatos para o seu interior; E) Fotomicrografia de enclave máfico da porção central, destacando fenocristais de plagioclásio (Pl) imersos em uma matriz equigranular fina com elevada porcentagem de quartzo; F) Xenocristal de quartzo (Qz) arredondado com textura ocelar, envolto por franjas de clinopiroxênio (augita) (Au) em enclave máfico da fácies porfirítica, porção nordeste do maciço. Figure 6. Macro and microscopic aspects of the Encruzilhada do Sul Granite and mafic rocks. A) Equigranular syenogranite from the central-east portion; B) Photomicrography of diorite from the southwest portion, with porphyritic texture defined by plagioclase phenocrysts (Pl) and low quartz content (light color) disseminated in the groundmass; C) Mafic enclaves in porphyritic monzogranite from the central portion; D) Mafic enclave in the central portion, with fracture filled by felsic material and mechanical migration of K-feldspar to its inner; E) Photomicrography of mafic enclave from the central portion highlighting plagioclase phenocrysts (Pl) involved by thin equigranular texture with high quartz content in the groundmass; F) Rounded xenocrystal of quartz $(Q z)$ with ocelar texture, surrounded by fringes of clinopyroxene (augite) (Au) in a mafic enclave of the porphyritic facies, northeast portion from the pluton. 


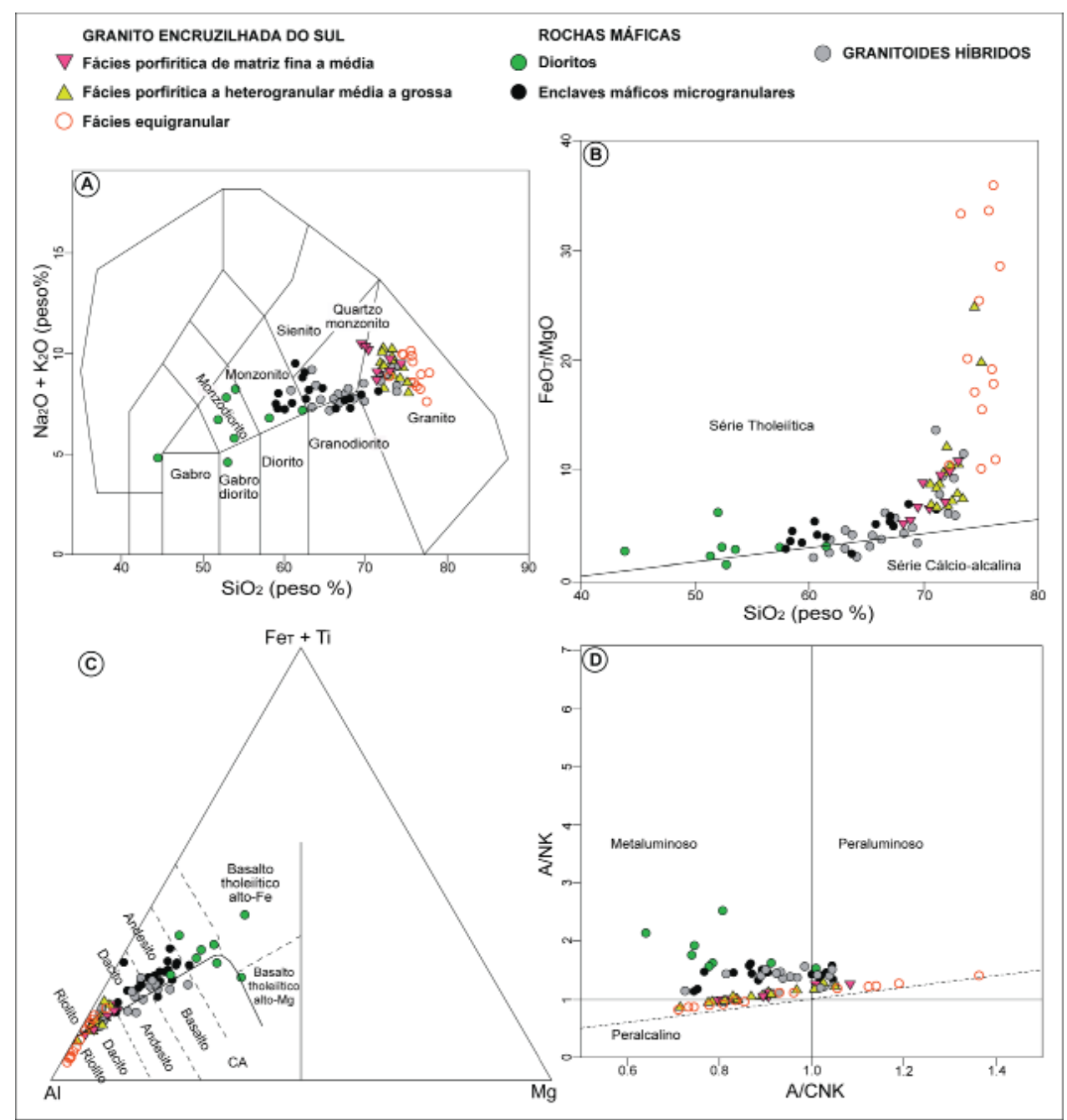

Figura 7. Diagramas geoquímicos contendo as amostras representativas da Suíte Encruzilhada do Sul. A) TAS (Middlemost, 1994); B) FeOT/MgO vs SiO2 (Miyashiro, 1974); C) (FeT+Ti)-Al-Mg (Jensen, 1976); D) A/NK vs A/CNK (Shand, 1943).

Figure 7. Geochemical diagrams containing the representative samples from Encruzilhada do Sul Suite. A) TAS (Middlemost, 1994); B) FeOT/MgO vs SiO2 (Miyashiro, 1974); C) (FeT+Ti)-Al-Mg (Jensen, 1976); D) A/NK vs A/CNK (Shand, 1943).

1,2 mm. A augita é rara, mostra formas subédricas e tamanho médio de $0,3 \mathrm{~mm}$, geralmente substituída por anfibólio. A apatita tem forma prismática alongada, euédrica e subédrica, menor que 0,1 $\mathrm{mm}$, inclusa no plagioclásio, hornblenda, biotita e K-feldspato. A titanita é euédrica e subédrica, com tamanhos de 0,2 a 0,6 mm, inclusa no K-feldspato e no quartzo anédrico. A magnetita tem forma octaédrica com tamanhos menores que $0,2 \mathrm{~mm}$. 0 zircão é euédrico, tetragonal nas seções basais com tamanhos inferiores a $0,1 \mathrm{~mm}$.

\subsubsection{Geoquímica}

Para determinar a composição do magmatismo máfico do GES, foram analisadas 27 amostras, sendo 8 dioritos, 10 enclaves máficos microgranulares e 9 granitoides híbridos (Tab. 1). Para fins de comparação, foram utilizados os dados de Vasquez (1997) de 9 amostras de monzogranitos da fácies porfirítica da borda nordeste, 15 da fácies porfirítica a heterogranular da porção central, 14 da fácies equigranular da porção central, 11 de granitoides híbridos e 9 de enclaves máficos.

A partir do diagrama TAS, que relaciona álcalis $\left(\mathrm{Na}_{2} \mathrm{O}+\mathrm{K}_{2} \mathrm{O}\right)$ vs $\mathrm{SiO}_{2}$ (Middlemost, 1994), observa-se que todas as fácies do GES, assim como as rochas máficas, são ricas em álcalis e sílica (Fig. 7A), dispondo-se no campo das rochas alcalinas. Os granitos apresentam concentrações elevadas do $\mathrm{SiO}_{2}$, entre 70 e $78 \%$, enquanto as rochas máficas mostram na sua maioria, valores acima de 50\%. Os granitoides híbridos apresentam concentrações intermediárias do $\mathrm{SiO}_{2}$ entre os granitos e as rochas máficas, entre 61 e 74\%. Com base neste diagrama, as rochas máficas são 


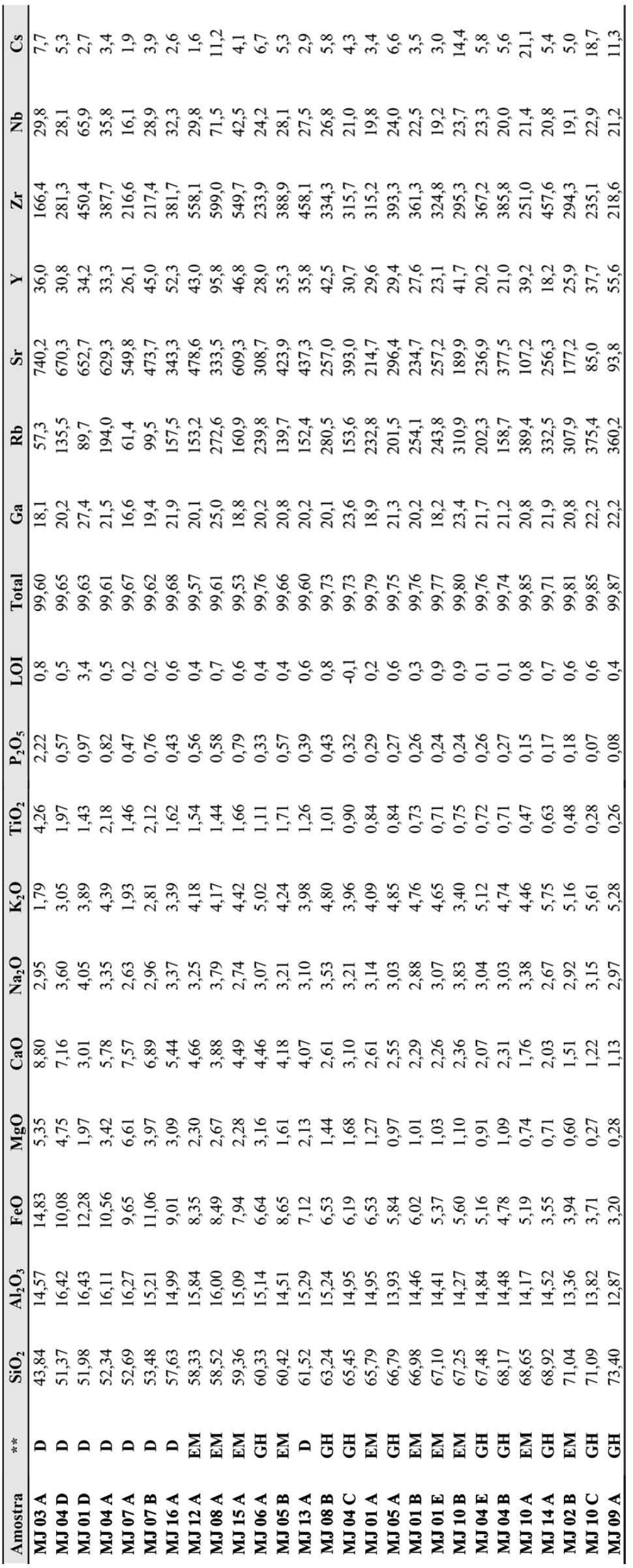




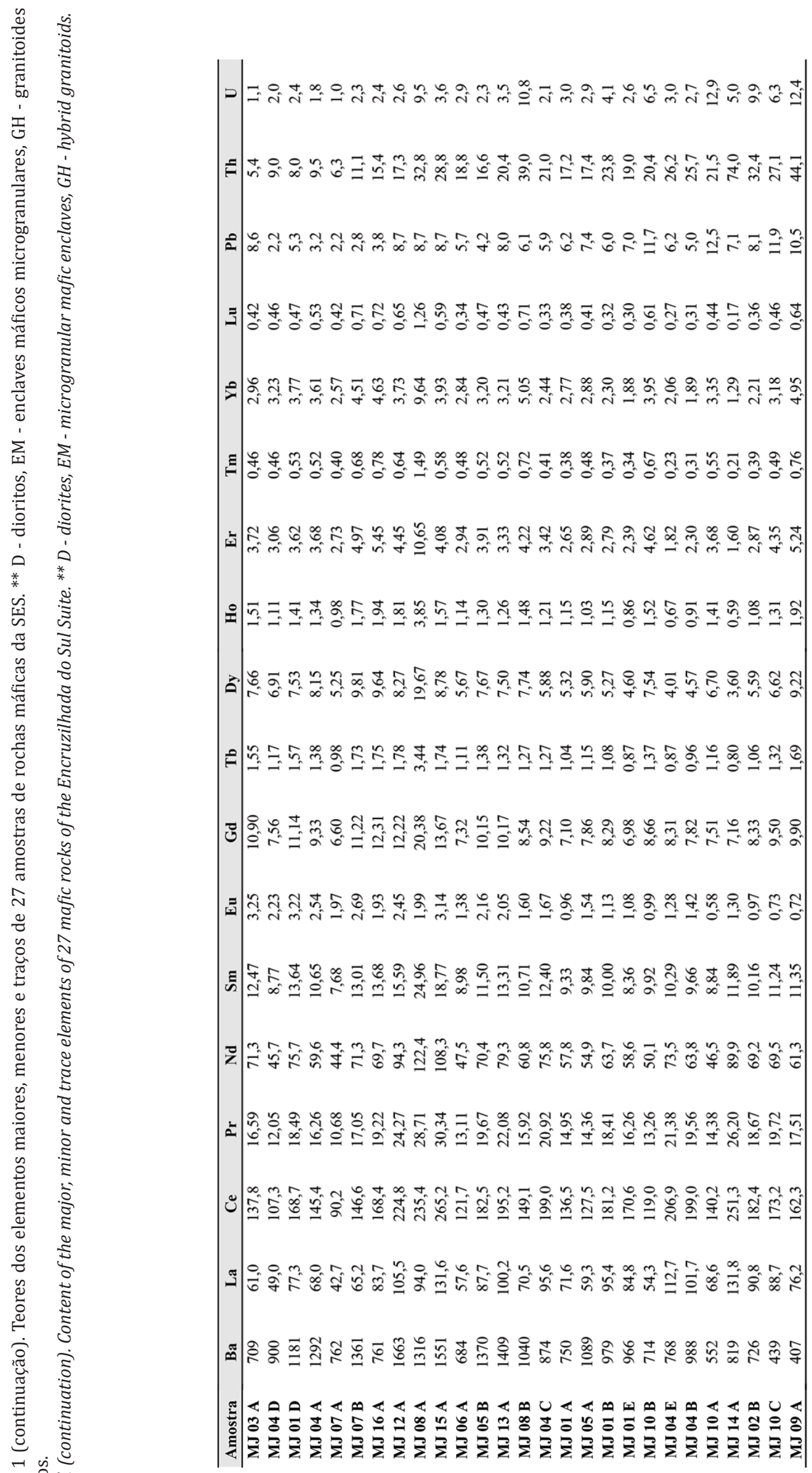


compostas por litologias variadas, tais como gabro, gabro-diorito, monzodiorito, monzonito, quartzo-monzonito e granodiorito. Os granitoides híbridos são compostos por quartzo-monzonitos, granodioritos e granitos. Nos diagramas $\mathrm{FeO}_{\mathrm{T}} /$ $\mathrm{MgO}$ vs $\mathrm{SiO}_{2}$ (Miyashiro, 1974) e (FeT+Ti)-Al-Mg (Jensen, 1976), as rochas máficas apresentam afinidade tholeiítica, enquanto os granitoides híbridos mostram afinidade tholeiítica e cálcicoalcalina (Figs. 7B e 7C). As fácies graníticas do GES plotam no campo das rochas tholeiíticas (Figs. 7B). No diagrama A/NK vs A/CNK (Shand, 1943), observa-se que as três fácies graníticas definidas neste estudo formam um trend entre os campos definidos para as rochas peralcalinas, metaluminosas e peraluminosas, os granitos equigranulares finos a médios mostram forte peraluminosidade (Fig. 7D). As rochas máficas e os granitoides híbridos são metaluminosos a levemente peraluminosos e constituem um trend único (Fig. 7D).

A disposição das amostras nos diagramas de Harker mostra boa correlação entre os elementos maiores e o $\mathrm{SiO}_{2}$, desde o extremo máfico até o extremo félsico, com as rochas híbridas mostrando composições intermediárias entre estes dois pólos (Fig. 8). Observa-se tendências bem definidas de diminuição dos teores de $\mathrm{FeO}_{\mathrm{T}}, \mathrm{MgO}, \mathrm{Al}_{2} \mathrm{O}_{3}, \mathrm{CaO}$, $\mathrm{TiO}_{2}$ e $\mathrm{P}_{2} \mathrm{O}_{5}$ com aumento do teor do $\mathrm{SiO}_{2}$ (Figs. 8A, 8B, 8C, 8D, 8G e 8H). As concentrações do $\mathrm{K}_{2} \mathrm{O}$ aumentam nas rochas máficas e nos granitoides com o aumento do SiO2 (Fig. 8E). O comportamento do $\mathrm{Na}_{2} \mathrm{O}$ apresenta elevada dispersão, com concentrações em geral muito elevadas para as rochas máficas (Fig. 8F).

A figura 9 relaciona as concentrações de $\mathrm{Ba}$, $\mathrm{Rb}, \mathrm{Sr}$ e $\mathrm{Zr}$ com o $\mathrm{SiO}_{2}$. As concentrações de $\mathrm{Ba}, \mathrm{Sr}$ e Zr são mais elevadas nos termos máficos e nos granitoides híbridos, em relação a composição das fácies graníticas (Figs. 9A, 9B e 9C). É possível observar que as concentrações de Rb e Sr mostram uma tendência contínua entre os termos máficos e os graníticos, respectivamente, com correlação positiva e negativa com o enriquecimento do $\mathrm{SiO}_{2}$ (Figs. 9D e 9B). Apesar da dispersão de Ba e Zr, nos termos máficos e nos granitoides híbridos, observa-se um enriquecimento com relação ao $\mathrm{SiO}_{2}$, enquanto os granitos mostram um empobrecimento (Figs. 9A e 9C).

Os padrões de elementos terras raras (ETR), normalizados pelo condrito de Boynton (1984), das fácies graníticas, granitoides híbridos e das rochas máficas são muito semelhantes e caracterizados por concentrações elevadas de ETR em relação aos valores condríticos. Todos os padrões estão marcados por um enriquecimento em ETR leves $\left(\operatorname{La}_{\mathrm{N}}\right.$ 142-427) em relação as ETR pesadas $\left(\mathrm{Lu}_{\mathrm{N}} 4-23\right)$ com razões LaN/LuN próximas de 15, com anomalias negativas do Eu mais pronunciadas para os granitos e um padrão horizontalizado de ETR pesadas, exceto para os monzogranitos da fácies porfirítica de matriz fina a média e para parte dos granitoides híbridos (Fig. 10).

Conforme as figuras $10 \mathrm{~A}, 10 \mathrm{~B}$ e $10 \mathrm{C}$ as razões $\mathrm{La}_{\mathrm{N}} / \mathrm{Lu}_{\mathrm{N}}$ das fácies graníticas variam aproximadamente entre 42 e 18, dos granitoides híbridos entre 38 e 19, enquanto nas rochas máficas entre 10 e 18. Os valores obtidos evidenciam semelhanças entre as fácies graníticas e os granitoides híbridos, enquanto as rochas máficas evidenciam razões mais baixas.

Os diagramas multi-elementares foram normalizados pelopadrão OIB (Ocean IslandBasalts, basaltos de ilhas oceânicas) definidos por Sun \& Mc Donough (1989). Este padrão foi selecionado por representar a composição de rochas enriquecidas pelo metassomatismo associado aos planos de subducção, como as rochas encaixantes e provável fonte do magmatismo granítico, caracterizadas pelos ortognaisses do Complexo Arroio dos Ratos. No diagrama da figura 11 observa-se a semelhança entre os padrões de todas as fácies graníticas e a semelhança entre estas e os granitoides híbridos. Os padrões observados entre as rochas máficas também são semelhantes e coerentes com rochas de uma mesma unidade. Quando comparados entre si os granitos e as rochas máficas mostram padrões semelhantes, diferindo apenas na intensidade das anomalias observadas. Destacam-se as anomalias negativas de $\mathrm{Ba}, \mathrm{Nb}, \mathrm{Sr}, \mathrm{P}$, Eu e Ti, com valores mais baixos para os granitos e granitoides híbridos quando comparados às rochas máficas. Destacamse ainda as anomalias positivas de Th, U e Y com valores maiores nos granitos em comparação as rochas máficas (Fig. 11). 


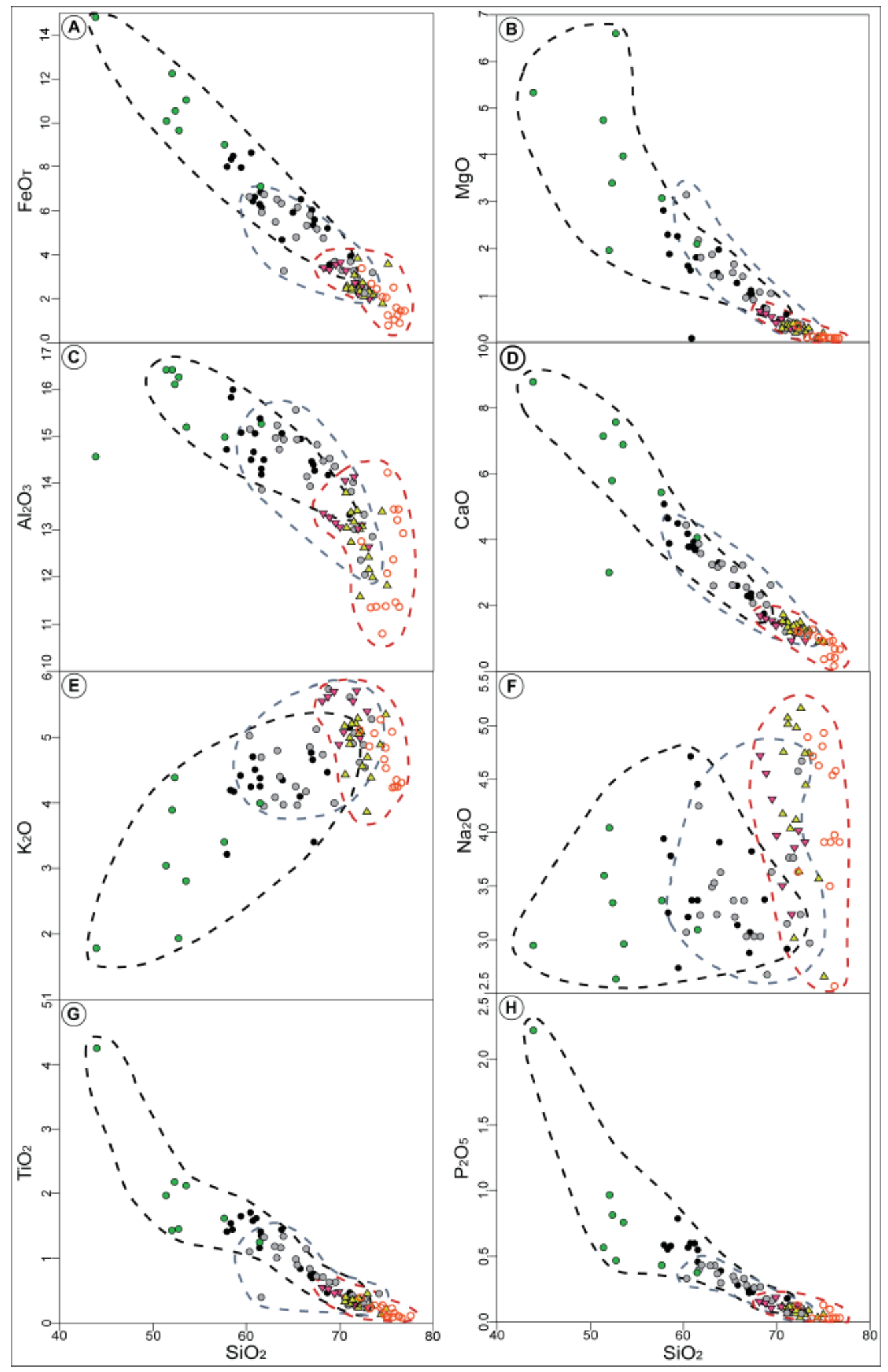

Figura 8. Diagramas de Harker para as litologias da SES mostrando o comportamento dos elementos maiores (\% peso), em função do $\mathrm{SiO}_{2}$. A) $\mathrm{FeO}_{\mathrm{T}}$ vs $\left.\mathrm{SiO} 2 ; \mathrm{B}\right) \mathrm{MgO}_{\text {vs }} \mathrm{SiO}_{2}$; C) $\mathrm{Al}_{2} \mathrm{O}_{3}$ vs $\mathrm{SiO} 2$; D) $\mathrm{CaO}$ vs $\mathrm{SiO}_{2}$; E) $\mathrm{K}_{2} \mathrm{O}$ vs $\mathrm{SiO}_{2}$; F) $\mathrm{Na}_{2} \mathrm{O}$ vs $\mathrm{SiO}_{2}$; G) $\mathrm{TiO}_{2}$ vs $\mathrm{SiO}_{2}$; H) $\mathrm{P}_{2} \mathrm{O}_{5}$ vs $\mathrm{SiO}_{2}$. Os símbolos são os mesmos da figura 7.

Figure 8. Harker diagrams for the lithologies from Encruzilhada do Sul Suite showing the behavior of major elements (wt \%), as a

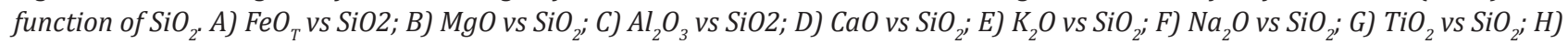
$\mathrm{P}_{2} \mathrm{O}_{5}$ vs $\mathrm{SiO}_{2}$. Symbols are the same as those for figure 7. 


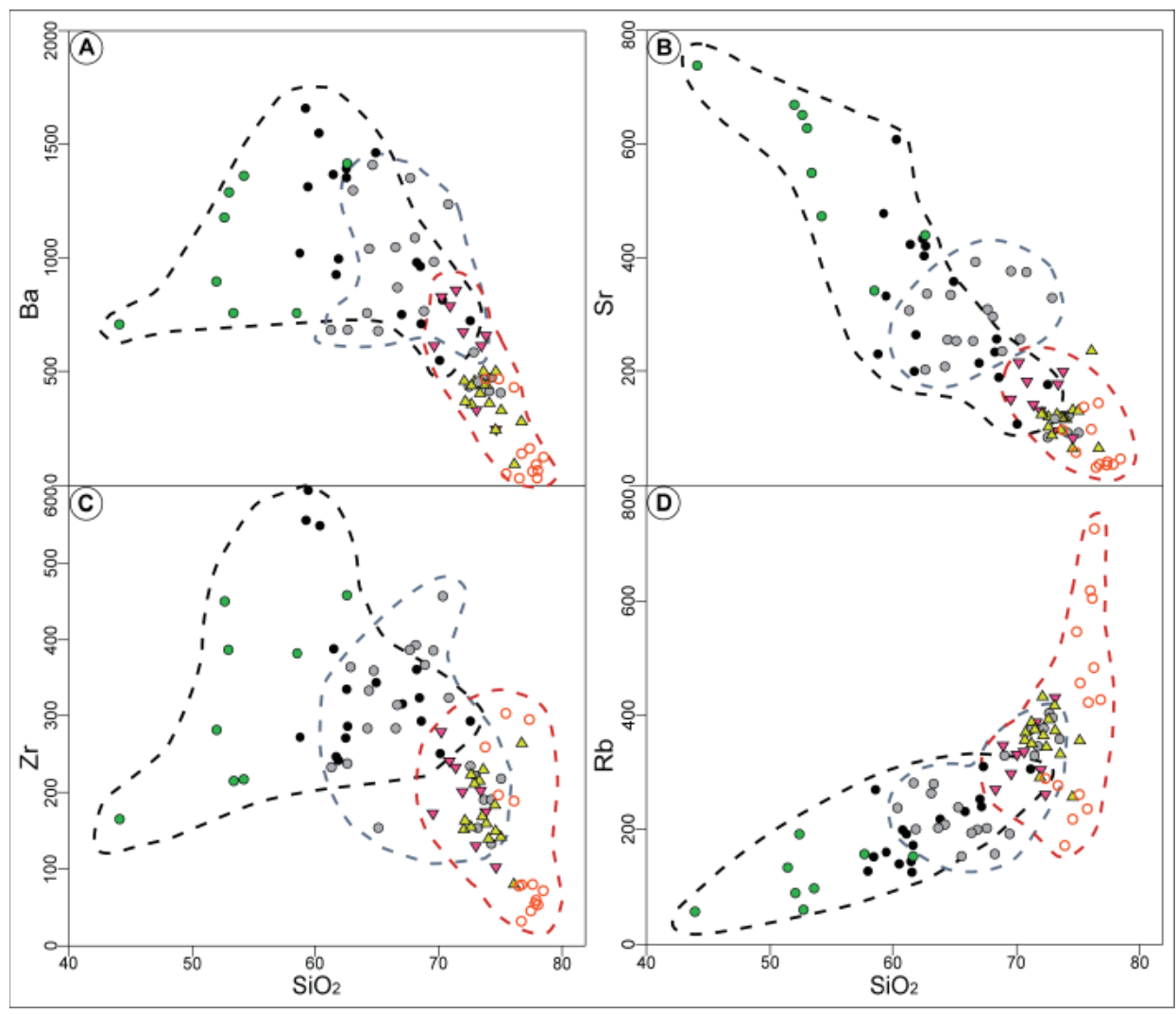

Figura 9. Diagramas de Harker mostrando o comportamento dos elementos traços (em ppm), em função do $\mathrm{SiO}_{2}$ das litologias

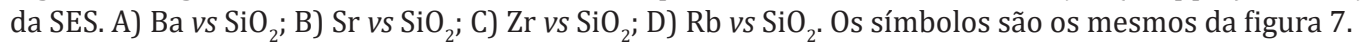

Figure 9. Harker diagrams showing the behavior of trace elements (in ppm) from lithologies of the Encruzilhada do Sul Suite. A) Ba vs $\mathrm{SiO}_{2}$; $\left.\mathrm{B}\right) \mathrm{Sr} v \mathrm{SiO}{ }_{2}$ C) $\mathrm{Zr} v \mathrm{SiO} \mathrm{Z}_{2}$, D) $\mathrm{Rb}$ vs $\mathrm{SiO}_{2}$. Symbols are the same as those for figure 7.

No diagrama $\mathrm{Rb}$ vs $\mathrm{Y}+\mathrm{Nb}$ (Pearce et al., 1984; Pearce, 1996), observa-se que o magmatismo granítico apresenta composição de ambiente intraplaca (Fig. 12A). Os diagramas de Batchelor \& Bodwen (1985), Eby (1992), Whalen et al. (1987) confirmam o caráter alcalino do magmatismo granítico como indicado por Vasquez (1997) (Figs. 12B, 12C e 12D).

\section{Discussão dos resultados}

\subsection{Zoneamento textural e composicional}

Os levantamentos de campo e os estudos petrográficos permitiram definir um zoneamento textural e composicional/mineralógico no GES. As distintas zonas caracterizam quatro fácies petrográficas e subdividem o corpo granítico em zonas de disposição concêntrica. A fácies porfirítica de matriz fina a média estendendo-se por toda a borda nordeste e sudoeste, transicionando para rochas porfiríticas a heterogranulares de matriz média a grossa até heterogranular muito grossa na porção central. A zonação textural é caracterizada principalmente pelo aumento do tamanho dos minerais, em especial dos megacristais de Kfeldspato em direção ao centro do corpo. Philipp \& Campos (2005) apresentaram parte desta faciologia e destacaram a importância da zonação textural e composicional dos granitos no seu aproveitamento como rocha ornamental. Os contatos entre as fácies são transicionais, e estão marcados por uma gradação textural e composicional, com variações no teor de minerais máficos, K-feldspato e de quartzo.

O zoneamento composicional está marcado pela diminuição do conteúdo de biotita e pelo aumento do conteúdo de quartzo e de K-feldspato em direção ao centro do granito. Esta variação composicional ainda está acompanhada pela diminuição do volume e pela variação da composição das rochas máficas. Os volumes mais significativos de corpos de dioritos e de zonas ricas em enclaves máficos estão associados a fácies de bordo do granito. Os enclaves máficos variam de composição, ocorrendo termos dioríticos a quartzo-dioríticos 


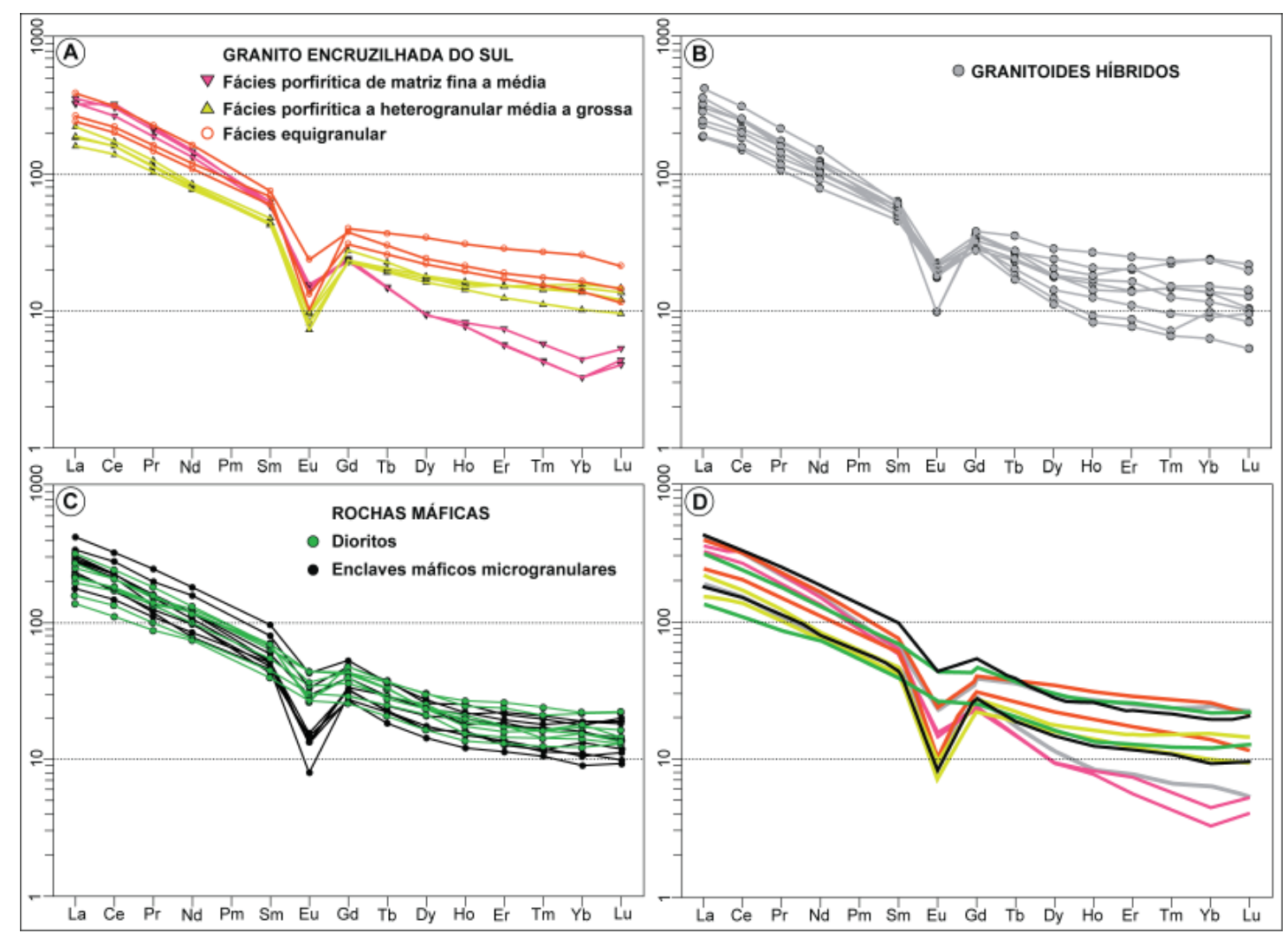

Figura 10. Padrões de elementos terras raras das amostras da SES normalizados para os valores condríticos (Boynton, 1984). A) Fácies graníticas; B) Granitoides híbridos; C) Rochas máficas; D) Diagrama comparativo entre todas as unidades. Legenda: preto- enclaves máficos, verde- dioritos, cinza- granitoides híbridos, rosa- fácies porfirítica de borda, amarelo- fácies porfirítica a heterogranular da porção central e laranja- fácies equigranular.

Figure 10. Patterns of rare earth elements from the samples of the Encruzilhada do Sul Suite, normalized to chondritic values (Boynton, 1984). A) Granitic facies; B) Hybrid granitoids; C) Mafic rocks; D) Comparative diagram between all units. Subtitle: black-mafic enclaves, green- diorites, gray-hybrid granitoids, pink- of the border porphyritic facies, yellow-central portion porphyritic to heterogranular facies and orange- equigranular facies.

na fácies de bordo, passando para termos quartzomonzodioríticos, tonalíticos e granodioríticos na porção central. Na fácies porfirítica de bordo também se observa um maior volume de granitoides híbridos. Estes granitos variam entre monzogranitos, granodioritos e quartzo-monzodioritos, todos com elevado conteúdo de minerais máficos (Biotita>Hornblenda) e de enclaves máficos.

A porção central do maciço representa a parte mais interna da câmara magmática, sendo caracterizada por granitos heterogranulares a equigranulares muito grossos e com elevada concentração e/ou acumulação de K-feldspato, elevados conteúdos de quartzo e diminuição da concentração de plagioclásio e biotita.

A fácies equigranular fina a média tem composição sienogranítica e ocorre na porção centronorte do maciço. Apresenta baixo teor de minerais máficos, teores mais elevados de K-feldspato e quartzo e ocorrência muito restrita de enclaves máficos. Estas características, associadas com a presença de bolsões pegmatíticos e corpos aplíticos sugerem que os granitos desta fácies representam as porções de cúpula parcialmente preservadas. Associado à esta fácies ainda ocorrem enxames de diques riolíticos, representando as fases finais do magmatismo.

\subsection{Mistura de magmas}

Os corpos de dioritos, os corpos tabulares de microdioritos e as zonas ricas em enclaves máficos atestam a contemporaneidade do magmatismo máfico presente no Granito Encruzilhada do Sul. Foram observadas estruturas e texturas indicativas de mistura homogênea (mixing) e heterogênea (mingling) entre os magmas ácido e básico. Dentre as feições características da contemporaneidade dos magmas, observam-se intrusões mútuas, com fraturas nos enclaves preenchidas por magma fél- 
sico, megacristais de K-feldspato no entorno dos enclaves, bem como a migração mecânica de Kfeldspato, quartzo e biotita para seu interior. Os contatos dos enclaves com os granitos apresentam limites curvilíneos a interlobados. Também são observados enclaves com formas angulosas indicando que durante a intrusão o magma máfico sofreu resfriamento rápido e inversão reológica, tornando-se mais viscoso que o magma granítico.

A mistura química ocorreu durante uma primeira fase de cristalização do magma, provavelmente, em condições de alta temperatura e com baixo percentual de cristais formados $(<30 \%)$. Nestas condições a mistura homogênea dos magmas gerou texturas e estruturas características, bem como propiciou a geração de granitoides híbridos como resultado da interação química entre os magmas. Estas feições são observadas em maior escala na fácies de bordo, representada por monzogranitos porfiríticos de matriz fina a média.
As exposições das fácies máficas no interior das fácies graníticas estão acompanhadas pelo aparecimento das texturas rapakivi e ocelar. Próximo às rochas máficas, a mistura química entre os magmas induziu a nucleação e o crescimento do plagioclásio ao redor dos cristais de K-feldspato e produziu a textura rapakivi. Os cristais de plagioclásio com as bordas e núcleos desestabilizados e corroídos, e com elevada concentração de inclusões de minerais máficos, caracterizam a textura "em peneira", indicando a mistura homogênea (mixing) entre magmas félsicos e máficos nas fases precoces da cristalização. 0 avanço da cristalização e do resfriamento do sistema resulta no aumento da viscosidade e densidade dos magmas, limitando a mistura homogênea e proporcionando o aparecimento de estruturas indicativas da mistura heterogênea (mingling), como os enclaves máficos de formas arredondadas até subangulosas, com contatos interlobados a interdigitados com os

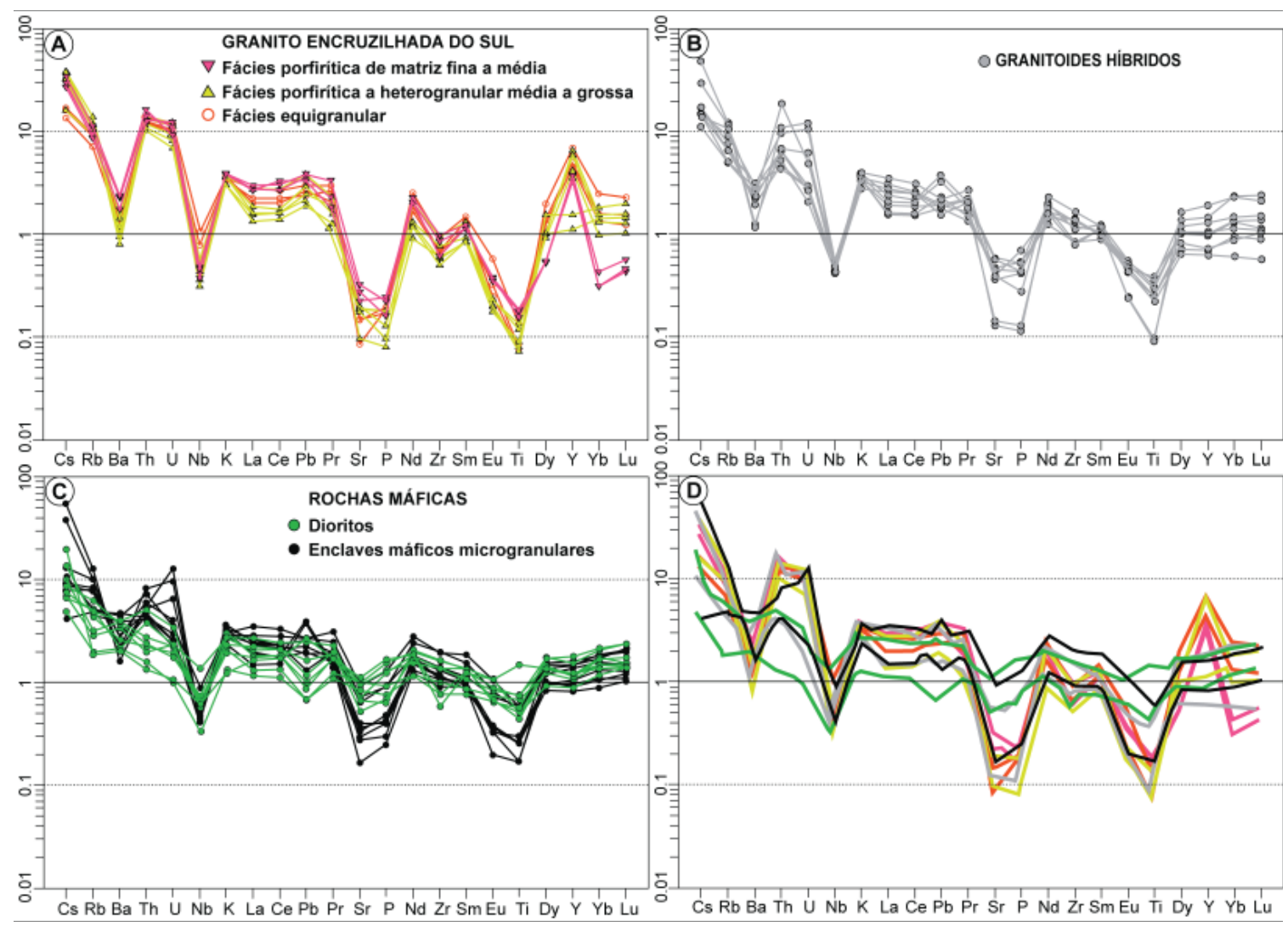

Figura 11. Diagramas multi-elementares das unidades da SES, normalizados para os valores de Ocean Island Basalts (OIB; Sun \& Mc Donough, 1989). A) Fácies graníticas do GES; B) Granitoides híbridos; C) Rochas máficas; D) Sobreposição das diversas unidades da SES. Legenda: preto- enclaves máficos, verde- dioritos, cinza- granitoides híbridos, rosa- fácies porfirítica de borda, amarelo- fácies porfirítica a heterogranular da porção central e laranja- fácies equigranular.

Figure 11. Multi-element diagrams of the Encruzilhada do Sul Suite units normalized to values of Ocean Island Basalts (OIB; Sun \& Mc Donough, 1989). A) Granitic facies; B) Hybrid granitoids; C) Mafic rocks; D) Overlapping of the various units. Subtitle: blackmafic enclaves, green-diorites, gray-hybrid granitoids, pink-porphyritic facies of the border, yellow-porphyritic to heterogranular facies of the central portion and orange- equigranular facies. 
granitos.

Os corpos máficos mais volumosos estão representados por dioritos e por corpos tabulares de microdioritos. 0 elevado conteúdo de rochas máficas associadas com a fácies de bordo sugere que o magmatismo máfico foi uma importante fonte de calor para a geração do magmatismo granítico.

\subsection{Nível de colocação}

Os contatos intrusivos com as rochas gnáissicas do embasamento e o padrão da zonação textural do maciço, marcados pela diminuição dos tamanhos dos cristais em direção às encaixantes,

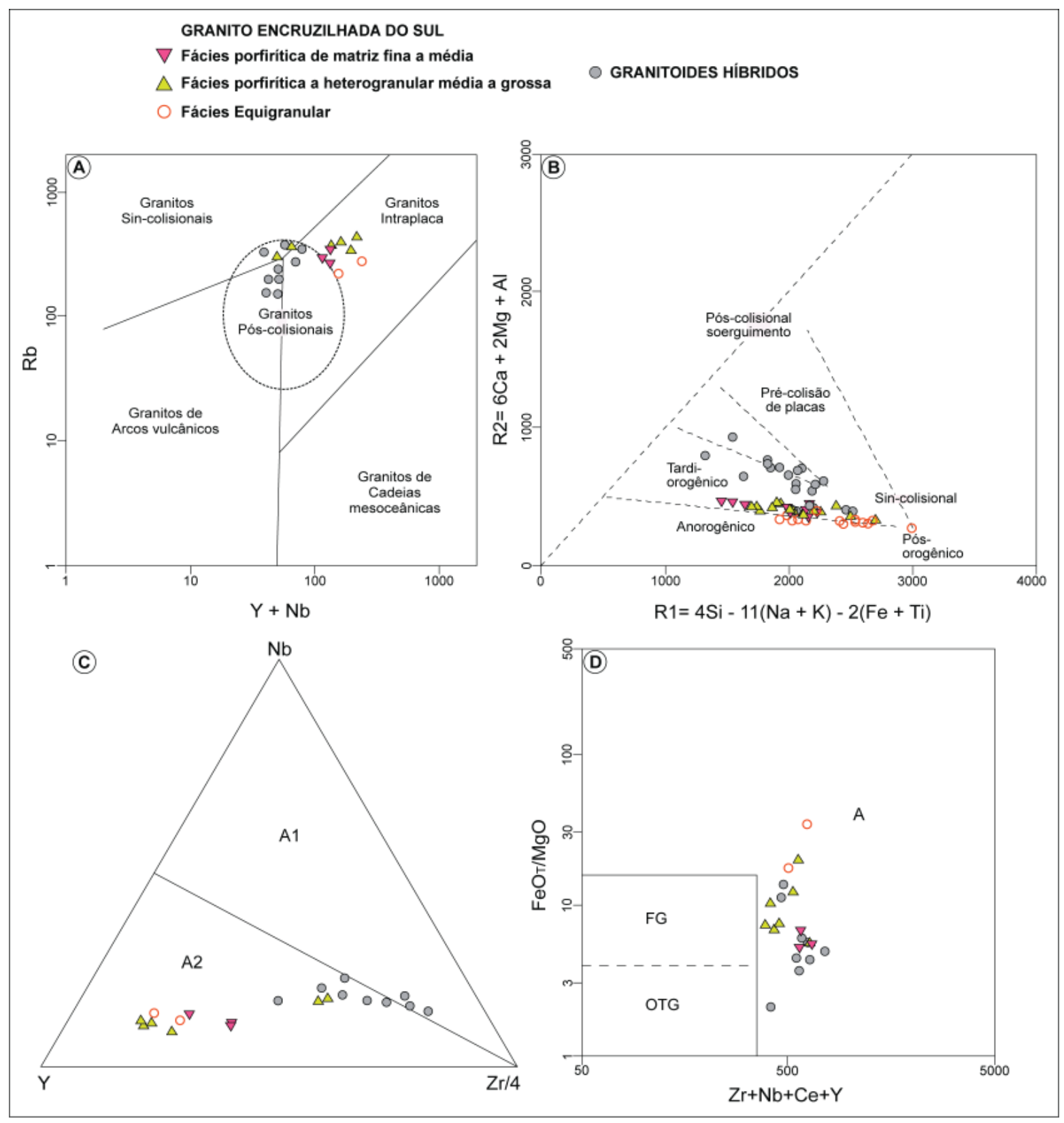

Figura 12. Representação das amostras dos granitos e granitoides híbridos da SES nos diagramas discriminantes de ambientes geotectônicos. A) Rb vs (Y+Nb) (Pearce et al., 1984; Pearce, 1996); B) R1-R2 (Batchelor \& Bodwen, 1985); C) Nb-Y-Zr/4 (Eby, 1992). Legenda: A1-granitos derivados de fontes mantélicas (OIB), A2- granitos derivados de fontes crustais; $\mathrm{D}$ ) $\mathrm{FeO}_{\mathrm{T}} / \mathrm{MgO} v \mathrm{~s}$ $\mathrm{Zr}+\mathrm{Nb}+\mathrm{Ce}+\mathrm{Y}$ (Whalen et al., 1987). Legenda: A- granito tipo-A, FG- granitos félsicos fracionados, OTG- granitos tipo M, I e S não fracionados.

Figure 12. Representation of the samples of the granites and hybrid granitoids of the Encruzilhada do Sul Suite in the geotectonic environments diagrams. A) Rb vs (Y+Nb) (Pearce et al., 1984; Pearce, 1996); B) R1-R2 (Batchelor \& Bodwen, 1985); C) Nb-Y-Zr/4 (Eby, 1992). Subtitle: A1-granites derived from mantle sources (OIB), A2- granites derived from crustal sources; D) $\mathrm{FeO} \mathrm{O}_{\mathrm{T}} / \mathrm{MgO}_{\mathrm{vS}}$ $\mathrm{Zr}+\mathrm{Nb}+\mathrm{Ce}+\mathrm{Y}$ (Whalen et al., 1987). Subtitle: A- granite type-A, FG- fractionated felsic granites, OTG- non-fractionated M, I and $S$ type granites. 
indica que o posicionamento do GES ocorreu em níveis crustais rasos. 0 metamorfismo colisional de Fácies Granulito que afetou os gnaisses encaixantes dos complexos Várzea do Capivarita e Arroio dos Ratos apresenta idades entre 650 e 620 Ma, obtidas pelo método U-Pb em zircão (Chemale Jr. et al., 2011; Gregory et al., 2015; Philipp et al., 2016a). A idade de cristalização dos granitos, de $594 \pm 5$ Ma (Babinski et al., 1997), é cerca de 50 a 30 Ma mais jovem. Essa variação temporal indica que o embasamento foi erodido e soerguido até níveis crustais superficiais e, posteriormente, foi intrudido pelos magmas da SES.

0 alongamento do maciço granítico segundo a direção $\mathrm{N} 30^{\circ} \mathrm{E}$ e o padrão de zoneamento concordante evidenciam que a ascensão e o posicionamento do GES foram controlados pela ZCDC. As feições de deformação rúptil observadas no granito reforçam que o posicionamento ocorreu em níveis crustais rasos, provavelmente relacionado a uma fase de reativação da ZCDC. A idade de cristalização e as condições rúpteis associadas a colocação do maciço sugerem que o posicionamento ocorreu em uma fase extensional relacionada com a deposição das rochas sedimentares e vulcânicas do Grupo Bom Jardim, da Bacia do Camaquã, encontradas a noroeste da SES.

A continuidade das exposições e a coerência estrutural dos gnaisses encaixantes caracterizam os mesmos como pendentes de teto (roof pendants). 0 intenso retrometamorfismo observado nos gnaisses é caracterizado por uma assembléia mineral hidratada e de baixa temperatura (epidoto + clorita + muscovita + actinolita), refletindo a transferência de calor e de fluidos relacionados ao magmatismo granítico. Uma estimativa com base na mineralogia metamórfica e com base num gradiente geotérmico entre 30 e $40^{\circ} \mathrm{C}$ para o estudo, sugere que a colocação do GES ocorreu em uma profundidade com cerca de 7 a $10 \mathrm{~km}$.

\subsection{Evolução geoquímica}

Os dados de campo e petrográficos associados com a composição geoquímica ressaltam a existência de três grupos principais de rochas: (i) fácies graníticas de composição ácida, (ii) dioritos e enclaves máficos de composições básicas a inter- mediárias (com raros enclaves híbridos de composições ácidas) e (iii) granitoides e enclaves máficos híbridos, com composições intermediárias a ácidas. Estas unidades representam dois pólos magmáticos distintos e uma zona de interação química representando uma variedade com relação as composições originais. Nos diagramas de Harker (Figs. 8 e 9), os elementos maiores apresentam "trends" contínuos e retilíneos, compostos pelos extremos básico (dioritos e enclaves máficos) e ácido (fácies graníticas), com uma zona intermediária caracterizada por granitoides e enclaves híbridos. Apesar da dispersão nos teores de $\mathrm{Na}_{2} \mathrm{O}$ (Fig. 8F) e, mais restrita no $\mathrm{K}_{2} \mathrm{O}$ (Fig. 8E), os padrões observados indicam dois magmas independentes cuja evolução magmática está associada principalmente com a cristalização fracionada. A evolução dos magmas básicos sugere o fracionamento de augita, hornblenda e plagioclásio, enquanto o magma granítico evoluiu através do fracionamento de plagioclásio, biotita e K-feldspato. Os padrões de ETR são muito semelhantes para os três grupos composicionais, ressaltando as anomalias do Eu mais pronunciadas nos granitos (Fig. 10). Os padrões observados nos diagramas multi-elementares destacam as principais diferenças entre os magmas ácido e básico, ressaltadas pelas acentuadas anomalias negativas de $\mathrm{Ba}, \mathrm{Nb}, \mathrm{Sr}, \mathrm{P}, \mathrm{Eu}, \mathrm{Ti}$ e $\mathrm{Yb}$, e positivas de Th, U e Y apresentadas pelas unidades graníticas (Fig. 11).

Os granitoides híbridos apresentam características comuns aos dois grupos principais e são interpretados como produto da mistura homogênea (mixing) entre os magmas ácido e básico ocorrida nas fases precoces de cristalização. Os trends retilíneos e contínuos observados nos diagramas de Harker para os elementos compatíveis indicam que as variações composicionais entre os extremos máfico e félsico se devem principalmente à mistura dos magmas.

Os enclaves máficos microgranulares ocorrem em maior volume e apresentam composições mais básicas na fácies granítica de borda do maciço em relação aos enclaves da porção central. Os dados referentes aos enclaves máficos, reforçados pela ocorrência significativa de faixas de granitoides híbridos indicam que os processos de mistura química prevaleceram na fácies de 
borda durante as fases iniciais de cristalização da câmara magmática.

A composição química do magmatismo máfico indica afinidade tholeiítica enriquecida em elementos LILE (Cs, $\mathrm{Rb}, \mathrm{Ba}$, Th, U) e em elementos terras raras leves. $\mathrm{O}$ enriquecimento em álcalis e $\mathrm{SiO}_{2}$ decorre provavelmente da contaminação dos magmas máficos durante o processo de mistura química. Apesar desta contaminação, as rochas dioríticas preservam feições típicas do magmatismo tholeiítico de afinidade continental, como o conteúdo elevado de $\mathrm{Al}_{2} \mathrm{O}_{3}$ (entre 14 e 18 $\%$ ) e das razões de $\mathrm{FeO}_{\mathrm{T}} / \mathrm{MgO}$ (Figs. 8C, 7B e 7C). As rochas graníticas apresentam padrões de elementos maiores e traços, particularmente terras raras leves, coerentes com líquidos originados por fusões crustais, como indicado pelo aumento da peraluminosidade (Fig. 7D) e os baixos valores de elementos como Zr e Nb (Figs. 9C e 11A). Os granitos da fácies equigranular fina a média são provavelmente o melhor exemplo de fusão crustal praticamente pura, enquanto as fácies porfiríticas a heterogranulares e equigranulares médias a grossas representam granitos do tipo-A, como os discutidos por Whalen et al., (1987), Eby (2006) e Nardi \& Bitencourt (2009) entre outros autores. Os diagramas de elementos traços confirmam a similaridade da composição dos granitos com o magmatismo intraplaca e pós-colisional (Fig. 12).

\subsection{Origem do magmatismo da SES}

A composição mineralógica e geoquímica indica que o magmatismo granítico do GES tem afinidade alcalina. A mineralogia do granito não apresenta anfibólio e/ou piroxênio alcalino, indicando que esta afinidade não é sódica. A ausência destes minerais e a presença de biotita sugere que o magmatismo alcalino pode ter uma origem crustal, conforme descrito por Barbarin (1990, 1997), Dall'Agnol \& Oliveira (2007) e Nardi \& Bitencourt (2009). 0 GES apresenta características de granitos tipo-A, demonstrada pela disposição dos elementos maiores, menores e traços em diagramas discriminantes como o TAS (Middlemost, 1994), A/NK vs A/CNK (Shand, 1943) (Figs. 7A e 7D), Rb vs (Y+Nb) (Pearce et al., 1984; Pearce, 1996), R1R2 (Batchelor \& Bodwen, 1985) e $\mathrm{FeO}_{\mathrm{T}} / \mathrm{MgO}$ vs
$\mathrm{Zr}+\mathrm{Nb}+\mathrm{Ce}+\mathrm{Y}$ (Whalen et al., 1987) (Figs. 12A, 12B e 12D). Esta característica também é observada no diagrama $\mathrm{Nb}-\mathrm{Y}-\mathrm{Zr} / 4$, discriminante de fontes do magmatismo alcalino proposto por Eby (1992), onde as fácies graníticas do GES plotam no campo A2, típico de rochas alcalinas geradas a partir de fontes crustais (Fig. 12C).

A geração de magmas alcalinos a partir da fusão da crosta é um processo provável a partir da fusão de rochas granulíticas desidratadas (Patiño-Dulce, 1995, 1999). As fusões crustais seriam originadas a partir da fusão parcial do embasamento granulítico representado pelos gnaisses dos complexos Várzea do Capivarita (Philipp et al., 2016a) e Arroio dos Ratos (Gregory et al., 2015), e subordinadamente, pelo Meta-anortosito Capivarita (Chemale Jr. et al., 2011). A fusão parcial do embasamento é estimulada pelo aumento do gradiente geotérmico promovido pela participação do magmatismo máfico associado.

A interação com os magmas máficos é evidenciada pelas relações de mistura química entre as fácies graníticas e os granitoides e enclaves híbridos, marcadas por amplas variações composicionais, texturais e mineralógicas. A interação física está registrada através dos enclaves máficos e corpos tabulares máficos, com contato interlobados definidos a gradacionais. Os dados geoquímicos também enfatizam esta gradação. Observa-se que entre os dois pólos composicionais representados pelas fácies graníticas do GES e pelas rochas máficas pouco diferenciadas, como enclaves microdioríticos, dioritos e gabros, ocorrem rochas graníticas e enclaves híbridos com composições transicionais marcadas nos elementos maiores e traços, incluindo os ETR. Do ponto de vista petrográfico observa-se nos granitoides híbridos uma composição variável de quartzo-monzodiorito, quartzomonzonito, monzonito e granodiorito, acompanhado pelo aumento do teor de minerais máficos, inversão de proporção entre (hornblenda>biotita) e entre (plagioclásio>K-feldspato), além da diminuição no teor de quartzo. Os enclaves máficos por sua vez, aumentam o teor de quartzo, K-feldspato e biotita, em detrimento da diminuição do conteúdo de hornblenda e plagioclásio. Esta interação também está refletida na composição geral das fácies graníticas do GES. $\mathrm{O}$ baixo teor do $\mathrm{MgO}$ e alta ra- 
zão $\mathrm{FeO}_{\mathrm{T}} / \mathrm{MgO}$ fazem que o granito apresente uma natureza tholeiítica nos diagramas de classificação (Figs. 8B e 7B).

O magma granítico do GES é de elevada temperatura, como indicado pela cristalização precoce do quartzo com forma facetada a globular no granito, pela intensidade da mistura química, pela ocorrência de amplas zonas enriquecidas em enclaves máficos microgranulares de composições distintas e evoluídas, e pela presença de granitoides e enclaves híbridos. Os cálculos da temperatura de cristalização com base no teor de $\operatorname{Zr}$ (Watson \& Harrison, 1983) indicaram que o magma granítico tinha temperaturas entre $770^{\circ}$ e $830^{\circ} \mathrm{C}$, corroborando as observações acima.

Os valores obtidos por Soliani Jr. (1986) e Vasquez (1997) para a razão ${ }^{87} \mathrm{Sr} /{ }^{86} \mathrm{Sr}$ do magmatismo granítico do GES, entre 0,712 e 0,716, reforçam a natureza crustal do mesmo. Babinski et al. (1997) também confirmaram as fontes crustais com a composição isotópica de $\mathrm{Sm}-\mathrm{Nd}$, onde o granito apresentou um valor de $\varepsilon_{\mathrm{Nd}(\mathrm{t})}$ de $-15,5$, com uma idade $\mathrm{T}_{\mathrm{DM}}$ de 2,08 Ga. Nardi \& Bitencourt (2009) descrevem que os granitos alcalinos póscolisionais da região sul do Brasil apresentam um magmatismo máfico contemporâneo. Os elementos traços e os isótopos sugerem que estas rochas apresentam uma variável contribuição de componentes crustais, principalmente de fontes como OIB (Ocean Islands Basalts) e EM1 (Enriched-mantle). Os autores propõem que o magmatismo alcalino pós-colisional do sul do Brasil sejam derivados de magmas mantélicos de composição básica ou intermediária a partir da atuação de processos de cristalização fracionada com participação variada de contaminação por fusões crustais.

\section{Conclusões}

Os dados petrográficos, mineralógicos e geoquímicos apresentados pelas fácies graníticas do Granito Encruzilhada do Sul sugerem que o mesmo foi gerado a partir do resfriamento de uma única câmara magmática. Esta câmara foi composta por dois magmas de composições distintas, com maior volume de rochas máficas na fácies porfirítica encontrada nas porções das bordas e de granitos na porção central. Os granitos da fácies equigranular fina a média que ocorrem na porção central do maciço são intrusivos nas outras fácies graníticas e representam as porções apicais da cúpula da câmara, bem como as margens resfriadas no contato com os gnaisses do embasamento.

A geração, ascensão e o posicionamento do maciço granítico foram controlados por uma fase de reativação com cinemática extensional da Zona de Cisalhamento Dorsal de Canguçu. A reativação desta zona gerou uma superfície de ruptura que atingiu a porção superior do manto promovendo, por fusão adiabática, a geração e ascensão de magmas mantélicos. Este magmatismo máfico promoveu o aumento do gradiente geotérmico regional e a fusão parcial da crosta granulítica desidratada anteriormente por processos de migmatização (Philipp et al., 2013, 2016a), originando uma associação ígnea bimodal composta pela interação entre os magmas granítico e máfico.

O magmatismo granítico tem composição alcalina potássica saturada em sílica, e o magmatismo máfico tem afinidade tholeiítica continental. Além de granitos e rochas máficas, observa-se um terceiro grupo representado por granitoides e enclaves máficos híbridos gerado por uma mistura homogênea (mixing) entre os magmas félsico e máfico em condições de alta temperatura e durante as fases precoces de cristalização. 0 avanço da cristalização e o resfriamento do sistema promoveram a interação heterogênea (mingling) entre os magmas e a formação dos enclaves máficos microgranulares. Os padrões geoquímicos das fácies graníticas definem estas rochas como granitos tipo-A, de afinidade tholeiítica. 0 magmatismo máfico apresenta feições características de rochas de afinidade tholeiítica continental.

Os dados estruturais e petrográficos indicam que o Granito Encruzilhada do Sul se posicionou em um nível crustal raso, durante o regime pós-colisional da orogênese Dom Feliciano, contemporâneo à deposição das rochas sedimentares e vulcânicas do Grupo Bom Jardim da Bacia do Camaquã, situada ao noroeste da SES.

Agradecimentos. 0 primeiro autor agradece ao Programa de Pós-Graduação em Geociências da UFRGS e à CAPES pela bolsa de mestrado, e ao 
financiamento das análises químicas através do projeto PRONEX FAPERGS/CNPq 10/0045-6. R.P. Philipp, E. Koester e L.V.S. Nardi agradecem ao CNPq pela concessão de bolsa de produtividade em pesquisa. Os autores agradecem aos revisores do trabalho, dentre eles Tiago Jalowitzki, e aos editores da revista Pesquisas em Geociências.

\section{Referências bibliográficas}

Atherton, M.P., McCourt, W.J., Sanderson, L.M. \& Taylor, W.P. 1979. The geochemical character of the segmented Peruvian Coastal Batholith and associated volcanics. In: Atherton, M.P. \& Tarney, J. (Eds.) Origin of granite batholiths: geochemical evidence, Exeter, Shiva Publishing Limited, p. 45-64.

Babinski, M., Chemale Jr., F., Van Schmus, W.R., Hartmann, L.A. \& Silva, L.C. 1997. U-Pb and Sm-Nd geochronology of the Neoproterozoic Granitic-Gneissic Dom Feliciano Belt, Southern Brazil. Journal of South American Earth Sciences, 10(3/4): 263-274.

Barbarin, B. 1990. Granitoids: main petrogenetic classifications in the relations to origin and tectonic setting. Geological Journal, 25: 227-238.

Barbarin, B. 1997. From the mineralogical composition of granitoids to their origins and tectonic settings. In: INTERNATIONAL SYMPOSIUM ON GRANITES AND ASSOCIATED MINERALIZATIONS, 2., 1997, Salvador, Anais ... Salvador, v.u., p. 95-97.

Batchelor, R.A. \& Bowden, P. 1985. Petrogenetic interpretation of granitoid rock series using multicationic parameters. Chemical Geology, 48: 43-55.

Bitencourt, M.F. \& Nardi, L.V.S. 1993. Late to post-collisional Brasiliano granitic magmatism in southernmost Brazil. Anais da Academia Brasileira de Ciências, 65(1): 3-16.

Bitencourt, M.F. \& Nardi, L.V.S. 2000. Tectonic setting and sources of magmatism related to the Southern Brazilian Shear Belt. Revista Brasileira de Geociências, 30: 184-187.

Bitencourt, M.F., Gastal, M.C.P., Kircheim, R.E., Costa, K.B. \& Toledo, F.A.L. 1993. Reavaliação preliminar das relações estratigráficas do Complexo Granítico Encruzilhada (CGE), RS. In: SIMPÓSIO
INTERNACIONAL DEL NEOPROTEROZÓICOCAMBRICO DE LA CUENCA DEL PRATA, MONTEVIDEO, 1., 1993, Uruguai. Boletim de Resumos Expandidos... Las Palomas-Minas, Montevideo, v. 2(34), p. 16-27.

Bitencourt, M.F., Bongiolo, E.M., Philipp, R.P., Morales, L.F.G., Rubert, R.R., Melo, C.L. \& Luft, JrJ.L. 2008. Estratigrafia do Batólito Florianópolis, Cinturão Dom Feliciano, na Região de Garopaba-Paulo Lopes, SC. Pesquisas em Geociências, 35(1): 109-136.

Bitencourt, M.F., Nardi, L.V.S., Florisbal, L.L. \& Heaman, L.M. 2015. Geology, geochronology and petrogenesis of a Neoproterozoic, syntectonic sillimanite-muscovite-biotite granite from southernmost Brazil. In: HUTTON SYMPOSIUM ON GRANITES AND RELATED ROCKS, 8., 2015, Florianópolis. Book of Abstracts ... Florianópolis, v. u., p. 153-153.

Bom, F.M., Philipp, R.P. \& Zvirtes, G. 2014. Evolução metamórfica e estrutural do Complexo Várzea do Capivarita, Cinturão Dom Feliciano, Encruzilhada do Sul, RS. Pesquisas em Geociências, 41(2): 131-153.

Boynton, W.V. 1984. Geochemistry of the Rare Earth Elements: meteorite studies. In: Henderson P. (Ed). Rare Earth Element Geochemistry. Amsterdam, Elsevier, p. 63-114.

Chappell, B.W. 1996. Magma mixing and the production of compositional variation within granite suites: evidence from the granites of Southeastern Australia. Journal of Petrology, 37(3): 449-470.

Chemale Jr., F. 2000. Evolução Geológica do Escudo Sul-rio-grandense. In: Holz, M. \& De Ros, L.F. (Eds.) Geologia do Rio Grande do Sul, Porto Alegre, Centro de Investigação do Gondwana, Instituto de Geociências, UFRGS, p. 13-52.

Chemale Jr., F., Philipp, R.P., Dussin, I., Formoso, M.L.L., Kawashita, K. \& Berttotti, A.L. 2011. Lu -Hf and U-Pb age determination of the Capivarita Anorthosite, Dom Feliciano Belt, Brazil. Precambrian Research, 186: 117-126.

Cobbing, E.J. \& Pitcher, W.S. 1972. The Coastal Batholith of the Central Peru. Journal of Geological Society of London, 128: 421-460.

Dall'Agnol, R. \& Oliveira, D.C. 2007. Oxidized, magnetite-series, rapakivi-type granites of Carajás, 
Brazil: Implications for classification and petrogenesis of A-type granites. Lithos, 93: 215-233.

Eby, G.N. 1992. Chemical subdivision of the A-type granitoids: petrogenetic and tectonic implications. Geology, 20: 641-644.

Eby, G.N. 2006. Distinctions Between A-type Granites and Petrogenetic Pathways, In: SYMPOSIUM ON MAGMATISM, CRUSTAL EVOLUTION, AND METALLOGENESIS OF THE AMAZONIAN CRATON, 2006, Belém. Abstracts Volume and Field Trips Guide... Belém, IGCP-510.

Eby, G.N., Krueger, H.W. \& Creasy, J.W. 1992. Geology, Geocronology, and geochemistry of the White Mountain Batholith, New Hampshire. Geological Society of America, Special Paper, 268: 379-397.

Fernandes, L.A.D., Tommasi, A. \& Porcher, C.C. 1992a. Deformation patterns in the southern Brazilian brach of the Dom Feliciano Belt: a reappraisal. Journal of South American Earth Science, 5(1): 77-96.

Fernandes, L.A.D., Tommasi, A., Porcher, C.C., Koester, E., Kraemer, G., Scherer, C.M.S. \& Menegat R. 1992b. Granitóides brasilianos precoces do Cinturão Dom Feliciano. Caracterização geoquímica e discussão estratigráfica. Pesquisas, 19(2): 197-218.

Figueiredo, M.C.H., Fragoso Cesar, A.R.S. \& Kronberg, B.J. 1990. Litogeoquímica das principais unidades do Batólito Pelotas no Rio Grande do Sul. In: CONGRESSO BRASILEIRO DE GEOLOGIA, 36., 1990, Natal. Anais... Natal, SBG, p.1723-1738.

Fragoso Cesar, A.R.S., Figueiredo, M.C.H., Soliani, Jr. E. \& Faccini, U.F. 1986. O Batólito Pelotas (Proterozóico Superior/Eo-Paleozóico) no Escudo do Rio Grande do Sul. In: CONGRESSO BRASILEIRO DE GEOLOGIA, 34., 1986, Goiânia. Anais... Goiânia, SBG, v.3, p.1322-1343.

Frantz, J.C., Lima, E.F., Machado, R.P. \& Naumann, M. 1984. Contribuição a geologia de Encruzilhada do Sul - RS. In: CONGRESSO BRASILEIRO DE GEOLOGIA, 33., 1984, Rio de Janeiro. Anais... Rio de Janeiro, SBG, v.5, p. 2407-2416.

Frantz, J.C., McNaughton, N.J., Marques, J.C., Hartmann, L.A., Botelho, N.F. \& Caravaca, G. 2003. Shrimp U-Pb zircon ages of granitoids from southernmost Brazil: constraints on the tem- poral evolution of the Dorsal de Canguçu transcurrent shear zone and the eastern Dom Feliciano belt. In: SOUTH AMERICAN SYMPOSIUM ON ISOTOPE GEOLOGY, 4., 2003, Salvador. Short Papers... Salvador, SBG, v.1, p.174-177.

Gregory, T.R., Bitencourt, M.F. \& Nardi, L.V.S. 2011. Caracterização estrutural e petrológica de metatonalitos e metadioritos do Complexo Arroio dos Ratos na sua seção-tipo, região de Quitéria, RS. Pesquisas em Geociências, 38(1): 85-108.

Gregory, T.R., Bitencourt, M.F., Nardi, L.V.S. \& Florisbal, L.M. 2015. Geochronological data from TTG-type rock associations of the Arroio dos Ratos Complex and implications for crustal evolution of southernmost Brazil in Paleoproterozoic times. Journal of South American Earth Sciences, 57: 49-60.

Hartmann, L.A., Leite, J.A.D., Silva, L.C., Remus, M.V.D., McNaughton, N.J., Groves, D.I., Fletcher, I.R., Santos, J.O.S. \& Vasconcellos, M.A.Z. 2000. Advances in SHRIMP geochronology and their impact on understanding the tectonic and metallogenic evolution of Southern Brazil. Australian Journal of Earth Sciences, 47: 829844.

Hartmann, L.A., Chemale Jr., F. \& Philipp, R.P. 2007. Evolução geotectônica do Rio Grande do Sul no Precambriano. In: Ianuzzi, R. \& Frantz, J.C. (Eds.). 50 Anos de Geologia. Instituto de Geociências. Contribuições, Porto Alegre, Editora Comunicação e Identidade, CIGO e IG-UFRGS, p.97-123.

Hibbard, M.J. 1995. Petrography to Petrogenesis. New Jersey, Prentice Hall, 604p.

Jensen, L.S. 1976. A new cation plot for classifying subalkalic volcanic rocks. Ontario Division of Mines, Miscellaneous Paper, 6: 1-22.

Koester, E., Fernandes, L.A.D., Soliani, Jr., E., Nardi, L.V.S., Kraemer, G. \& Roisenberg, A. 2001. Granitóides sintectônicos à Zona de Cisalhamento Transcorrente Dorsal de Canguçu, RS: Geologia e Geoquímica. Revista Brasileira de Geociências, 31: 141-154.

Martil, M.M.D., Bitencourt, M.F. \& Nardi, L.V.S. 2011. Caracterização estrutural e petrológica do magmatismo pré-colisional do Escudo Sul -rio-grandense: os ortognaisses do Complexo Metamórfico Várzea do Capivarita. Pesquisas 
em Geociências, 38(2): 181-201.

Middlemost, E.A.K. 1994 Naming materials in the magma/igneous rock system. Earth Science Review, 37: 215-224.

Miyashiro, A. 1974. Volcanic rock series in island arcs and active continental margins. American Journal of Science, 274: 321-355.

Nardi, L.V.S. \& Bitencourt, M.F. 2007. Magmatismo granítico e evolução crustal do sul do Brasil. In: Ianuzzi, R. \& Frantz, J.C. (Eds.). 50 Anos de Geologia. Instituto de Geociências. Contribuições. Porto Alegre, Editora Comunicação e Identidade, CIGO e IG-UFRGS. p.125-141.

Nardi, L.V.S. \& Bitencourt, M.F. 2009. A-type granitic rocks in post-collisional settings in southernmost Brazil: their classification and relationship with tectonics and magmatic series. The Canadian Mineralogist, 47: 1493-1503.

Oyhantçabal, P., Siegesmund, S. \& Wemmer, K. 2011. The Rio de la Plata Craton, a review of units, boundaries, ages and isotopic signature. International Journal of Earth Sciences. 100: 201-220.

Oyhantçabal, P., Siegesmund, S., Wemmer, K., Frei, R. \& Layer, P. 2007. Post-collisional transition from calc-alkaline to alkaline magmatism during transcurrent deformation in the southernmost Dom Feliciano Belt (Braziliano-Pan-African, Uruguay). Lithos, 98: 141-159.

Oyhantçabal, P., Siegesmund, S., Wemmer, K. Frei, R. \& Layer, P. 2009. Geochronological constraints on the evolution of the southern Dom Feliciano Belt (Uruguay). Journal of the Geological Society of London, 166: 1-11.

Patiño-Douce, A.E. 1995. Experimental generation of hybrid silicic melts by reaction of High-Al basalt with metamorphic rocks. Journal of Geophysical Research, 100(B8): 15623-15639.

Patiño-Douce, A.E. 1999. What do experiments tell us about the relative contributions of crust and mantle to the origin of granitic magmas? In: Castro, A., Fernandez, C. \& Vigneresse, J.L. (Eds). Understanding Granites. Integrating new and classical techniques. Geological Society, London, Special Publications, 158: 55-75.

Pearce, J.A. 1996. Sources and settings of granitic rocks. Episodes, 19(4): 120-125.

Pearce, J.A., Harris, N.B.W. \& Tindle, A.G. 1984. Tra- ce element discrimination diagrams for the tectonics interpretations of granitic rocks. Journal of Petrology, 25: 956-983.

Philipp, R.P. 1990. Geologia e Petroquímica dos granitóides da região de Monte Bonito, Pelotas, RS. Porto Alegre. 231p. Dissertação de Mestrado, Programa de Pós-Graduação em Geociências, Instituto de Geociências, Universidade Federal do Rio Grande do Sul.

Philipp, R.P. \& Machado, R. 2001. Estratigrafia e Significado Tectônico das Suítes Graníticas do Batólito Pelotas no RS. Revista Brasileira de Geociências, 31(3): 257-266.

Philipp, R.P. \& Campos, R.S. 2005. Controles geológicos das jazidas de granitos ornamentais da região de Encruzilhada do Sul, RS: origem das variedades comerciais do Granito Encruzilhada do Sul. Pesquisas em Geociências, 32(1): 37-49.

Philipp, R.P. \& Machado, R. 2005. The Late Neoproterozoic to Cambrian Granitic Magmatism of Pelotas Batholith, Southern Brazil. Journal of South American Earth Science, 19: 461-478.

Philipp, R.P., Mesquita, M.J., Gomes, M.E.B. \& Almeida, D.P.M. 1993. Reconhecimento estrutural e geoquímico dos Granitóides Brasilianos da região de Pelotas, RS. Pesquisas, 20(1): 3-13.

Philipp, R.P., Nardi, L.V.S. \& Machado, R. 1998. O Magmatismo Granítico Neoproterozóico tardi a pós-colisional da região de Porto Alegre, RS. In: CONTRIBUIÇÃO AO ESTUDO DOS GRANITOS E ROCHAS CORRELATAS. Publicação Especial... Núcleo Bahia-Sergipe, SBG, v.5, p.129-152.

Philipp, R.P., Nardi, L.V.S. \& Bitencourt, M.F. 2000.0 Batólito Pelotas no Rio Grande do Sul. In: Holz, M. \& De Ros, L.F. (Eds.) Geologia do Rio Grande do Sul, Porto Alegre, Centro de Investigação do Gondwana, Instituto de Geociências, UFRGS, p.133-160.

Philipp, R.P., Machado, R., Nardi, L.V.S. \& Lafon, J.M. 2002. O magmatismo granítico Neoproterozóico do Batólito Pelotas no sul do Brasil: novos dados e revisão da geocronologia regional. Revista Brasileira de Geociências, 32(2): 277-290.

Philipp, R.P., Machado, R. \& Chemale Jr., F. 2003. Reavaliação e novos dados geocronológicos (Ar/ $\mathrm{Ar}, \mathrm{Rb} / \mathrm{Sr}$ e Sm/Nd) do Batólito Pelotas no Rio Grande do Sul: implicações petrogenéticas e idade de reativação das zonas de cisalhamento. 
Geologia USP, Série Científica, 3: 71-84.

Philipp, R.P., Chemale Jr., F. \& Machado, R. 2007. A geração dos granitóides Neoproterozóicos do Batólito Pelotas: evidências dos isótopos de $\mathrm{Sr}$ e Nd e implicações para o crescimento continental da porção sul do Brasil. In: Frantz, J.C. \& Ianuzzi, R. (Eds.), 50 Anos de Geologia. Instituto de Geociências. Contribuições. Porto Alegre, Editora Comunicação e Identidade, CIGO e IG-UFRGS. p. 59-77.

Philipp, R.P., Lusa, M. \& Nardi, L.V.S. 2008. Geochemistry and petrology of dioritic, tonalitic and trondhjemitic gneisses from Encantadas Complex, Santana da Boa Vista, Southernmost Brazil: A Paleoproterozoic continental-arc magmatism. Anais da Academia Brasileira de Ciências, 80(4): 1-14.

Philipp, R.P., Formoso, M.L., Dussin, I., Chemale Jr., F. \& Campos, R.S. 2010. Estruturas primárias e tectônicas do Anortosito Capivarita, Pântano Grande, RS: significado e implicações para o entendimento da evolução petrológica. Revista Brasileira de Geociências, 40: 99-110.

Philipp, R.P., Massonne, H.J. \& Campos, R.S. 2013. Peraluminous leucogranites of the Cordilheira Suite: A record of Neoproterozoic collision and the generation of the Pelotas Batholith, Dom Feliciano Belt, Southern Brazil. Journal of South American Earth Sciences, 43: 8-24.

Philipp, R.P., Bom, F.M., Pimentel, M.M., Junges, S.L. \& Zvirtes, G. 2016a. SHRIMP U-Pb age and high temperature conditions of the collisional metamorphism in the Várzea do Capivarita Complex: implications for the origin of Pelotas Batholith, Dom Feliciano Belt, southern Brazil. Journal of South American Earth Sciences, 66: 196-207.

Philipp, R.P., Pimentel, M.M. \& Chemale Jr., F. 2016b. Tectonic evolution of the Dom Feliciano belt in southern Brazil based on geological relationships and U-Pb geochronology. Brazilian Journal of Geology, 46(1): 83-104.

Picada, R.S. 1971. Ensaio sobre a tectônica do Escudo Sul-riograndense. In: CONGRESSO BRASILEIRO DE GEOLOGIA, 25., 1971, São Paulo. Anais... São Paulo, SBG, v.1, p.167-191.

Picada, R.S. \& Tessari, R.I. 1970. Geologia da Folha de Pinheiro, Encruzilhada do Sul, RS. Boletim da Escola de Geologia, Universidade do Rio Grande do Sul, Porto Alegre, 15: 1-41.

Pitcher, W.S. 1993. The nature and origin of granite. London, Blackie Academic \& Professional, $321 \mathrm{p}$.

Ramgrab, G.E., Wildner, W. \& Camozzato, E. 1997. Mapa Geológico da Folha Porto Alegre, SH. 22-Y-B, Estado do Rio Grande do Sul. Escala 1.250:000. Programa de Levantamentos Geológicos Básicos, Brasília, CPRM, 144p.

Rapela, C.W., Fanning, C.M., Casquet, C., Pankhurst, R.J., Spaletti, L., Poiré, D. \& Baldo, E.G. 2011. The Rio de La Plata craton and the adjoining Pan-African-Brasiliano terranes: their origins and incorporation into south-west Gondwana. Gondwana Research, 20: 673-690.

Saalman, K., Gerdes, A., Lahaye, Y., Hartmann, L.A., Remus, M.V.D. \& Läufer, A. 2010. Multiple accretion at the eastern margin of the Rio de La Plata craton: the prolonged Brasiliano orogeny in southernmost Brazil. International Journal of Earth Sciences, 100: 355-378.

Shand, S.J. 1943. Eruptive Rocks. Their Genesis, Composition, Classification, and Their Relation to Ore-Deposits with a Chapter on Meteorite. New York, John Wiley \& Sons, 488p.

Soliani Jr., E. 1986. Os dados geocronológicos do Escudo Sul-rio-grandense e suas implicações de ordem geotectônica. Porto Alegre. 425 p. Tese de Doutorado, Programa de Pós-Graduação em Geociências, Instituto de Geociências, Universidade de São Paulo.

Streckeisen, A.L. 1976. To each plutonic rock, its proper name. Earth Science Review, 12: 1-33.

Sun, S.S. \& Mc Donough, W.F. 1989. Chemical and isotopic systematics of oceanic basalts: implications for mantle composition and processes. In: Sounders, A.D. \& Norry, M.J. (Eds.), Magmatism in the ocean basins. Geological Society London Special Publication, 42, p.313-345.

Tessari, R.I. \& Picada, R.S. 1966. Geologia da Quadrícula de Encruzilhada do Sul, RS, Brasil. Boletim da Divisão de Fomento da Produção Mineral, DNPM, 124: 1-147.

UFRGS. Universidade Federal do Rio Grande do Sul. 2008. Mapeamento Geológico 1:25.000, de parte das folhas Passo das Canas e Capané, RS. Trabalho de Graduação do Curso de Geologia, Instituto de Geociências, Universidade Federal 
do Rio Grande do Sul.

UFRGS. Universidade Federal do Rio Grande do Sul. 2009. Mapeamento Geológico 1:25.000, de parte da folha de Passo das Canas, RS. Trabalho de Graduação do Curso de Geologia, Instituto de Geociências, Universidade Federal do Rio Grande do Sul.

UFRGS. Universidade Federal do Rio Grande do Sul. 2010. Mapeamento Geológico 1:25.000, de parte das folhas de Encruzilhada do Sul e Passo das Canas, RS. Trabalho de Graduação do Curso de Geologia, Instituto de Geociências da Universidade Federal do Rio Grande do Sul.

UFRGS. Universidade Federal do Rio Grande do Sul. 2011. Mapeamento Geológico 1:25.000, de parte da folha de Várzea do Capivarita, RS. Trabalho de Graduação do Curso de Geologia, Instituto de Geociências, Universidade Federal do Rio Grande do Sul.

Vasquez, M.L. 1997. Evolução petrogenética dos granitos da Suíte Intrusiva Encruzilhada do Sul, $R S$. Porto Alegre, 195p. Dissertação de Mestrado, Programa de Pós-Graduação em Geociências, Instituto de Geociências, Universidade Federal do Rio Grande do Sul.

Ventzke, S.O. 2007. Mapeamento e Caracterização Tecnológica das Rochas Máficas associadas ao Granito Encruzilhada (Suíte Encruzilhada do Sul), RS. Porto Alegre, 64p. Monografia da Conclusão de Curso, Curso de Geologia, Instituto de Geociências, Universidade Federal do Rio Grande do Sul.

Vernon, R.H. 1983. Restite, xenoliths and microgranitoid enclaves in granites. Journal and Proceedings of Royal Society of New South Wales, Australia, 116: 77-103.

Vernon, R.H. 1986. K-feldspar megacrysts in granites: phenocrysts, not porphyroblasts. Earth-Science Reviews, 23: 1-63.

Watson, E.B. \& Harrison, T.M. 1983. Zircon saturation revisited: temperature and composition effects in a variety of crustal magma types. Earth and Planetary Science Letters, 64: 295-304.

Whalen, J.B., Currie, K.L. \& Chappell, B.W. 1987. Atype granites: geochemical characteristics discrimination and petrogenesis. Contributions to Mineralogy and Petrology, 95: 407-419.

Wildner, W., Ramgrab, G.E., Lopes, R.C. \& Iglesias, C.M.F. 2007. Mapa Geológico do Estado do Rio Grande do Sul. Programa Geologia do Brasil, Superintendência Regional de Porto Alegre. v. 1, escala 1:750.000. 